\title{
HOLOCENE DIATOMS FROM GULF OF SUEZ SEDIMENTS, EGYPT
}

\author{
Ahmed A. El-Awamri and Hesham M. Abd El Fatah \\ Botany Department, Faculty of Science, Ain Shams University, Cairo, Egypt
}

\begin{abstract}
Marine Holocene fossil diatoms were studied from different locations along the Gulf of Suez. Quantitative and qualitative diatom analyses from the sea floor sediments of the Gulf of Suez at different depths were used to evaluate the paleo-environmental conditions during the Holocene. Sea floor samples were taken from twelve locations at different depths ranging from 15 to $275 \mathrm{ft}$. below sea level. A total of 106 taxa related to 48 genera were identified from 12 sediment samples examined from the north, middle and south of the Gulf of Suez at different depths. Those diatom taxa were used according to their habitat preferences and ecological conditions to predict the water quality fluctuations during the Holocene.
\end{abstract}

Keywords: Diatoms, phytoplankton, Gulf of Suez, paleoenvironment, Holocene, marine diatoms.

\section{Introduction}

Fossil diatoms have been widely used to reconstruct past changes in $\mathrm{pH}$, salinity, nutrients and climatic changes (Fritz, 1990; Fritz et al., 1991 and 1993; Brooks et al., 2001 and Taffs, 2001). Their indicator value is based on their welldefined ecological tolerances (Laušević and Cvijan, 1994). They are the best indicators of the physical and chemical conditions (Dixit et al., 1992; Cate et al., 1993; Van Dam 1993; Kashima, 1994; Patrick and Papavage, 1994 and SilvaBenavides, 1996; Rigual-Hernández et al., 2013). Developments in diatom analysis have also been promoted by improvements in sediment coring (Wright, 1980 and Glew, 1991) and dating (Pennington et al., 1973; Appleby et al., 1986; Appleby and Oldfield, 1988) and in the availability of powerful numerical techniques (ter Braak, 1986; Birks, 1995 and 1998) that together enable robust quantitative reconstruction of environmental change to be made (Battarbee $\boldsymbol{\&}$ Renberg, 1990).

Although Egypt is cornered between two large water bodies, the Mediterranean Sea and the Red Sea, and despite the extensive work on fossil diatoms in almost all water bodies from the Antarctic to the Indian Ocean, it is noticeable that a few literatures have been focusing on the study of fossil diatoms in Egypt. 
Studies on fossil diatoms in Egypt consists mainly of the work of Aleem (1958) which surveyed taxonomically and paleoecologically the diatom flora of the extinct Fayoum Lake; Sadek (1978) which studied nannofossils and diatoms from some Pliocene sediment of North-Western desert of Egypt at Salum area; El-Awamri (1984) studied fossil diatom samples from Pleistocene and Upper Eocene ages collected from Lake Moreis; Zalat (1995, 1997) which studied diatoms from the Quaternary sediments of the Nile Delta and their paleoecological significance and studied the distribution of Holocene diatoms in bottom sediments of Lake Timsah; Flower et al. (2006) which estimated an assessment of recent paleolimnological records in Lake Quarun, and concluded from this data the environmental changes at the desert margin in Egypt; Flower et al. (2013) studied Stephanodiscus species from Holocene sediments in the Faiyum Depression (Middle Egypt).

From the previous literatures, it is apparent that there are few studies on the fossil diatoms of Gulf of Suez whereas studies were focused on Geological and Foraminifera analysis.

Concerning the studied area (Gulf of Suez), recent diatom flora was studied by Sukhanova (1969), Halim (1976), Zalat (2002) and El-Shahed (2006). While fossil diatoms were studied by Abdel Salam and El-Tablawy (1970) who reported the occurrence of diatoms in the Zeit Formation, The diatom assemblages recovered are formed of 23 species belonging to 12 genera, Five diatom species of these assemblages belonging to four genera were strictly of Pliocene age, the other diatom species range from Miocene to Recent; Tawfic and Krebs (1994) who documented the presence of marine and non-marine diatoms in the thin, fine-grained beds within the evaporites and clastics found within the Zeit Formation in the central and southern portions of the Gulf of Suez; Ahmed and Pocknall (1994) who briefly discussed the presence of palynomorphs within the evaporites and interbedded clastics of Suez Gulf; Ali et al., (2010) studied fossil diatoms in Zaafarana formation.

This study was mainly undertaken to throw light on marine Holocene fossil diatoms of the Gulf of Suez, Egypt and predict some of its paleoecological and paleoclimatic conditions.

\section{Material and Methods}

Sea floor samples were collected from twelve locations along the Gulf of Suez (Fig. 1). 


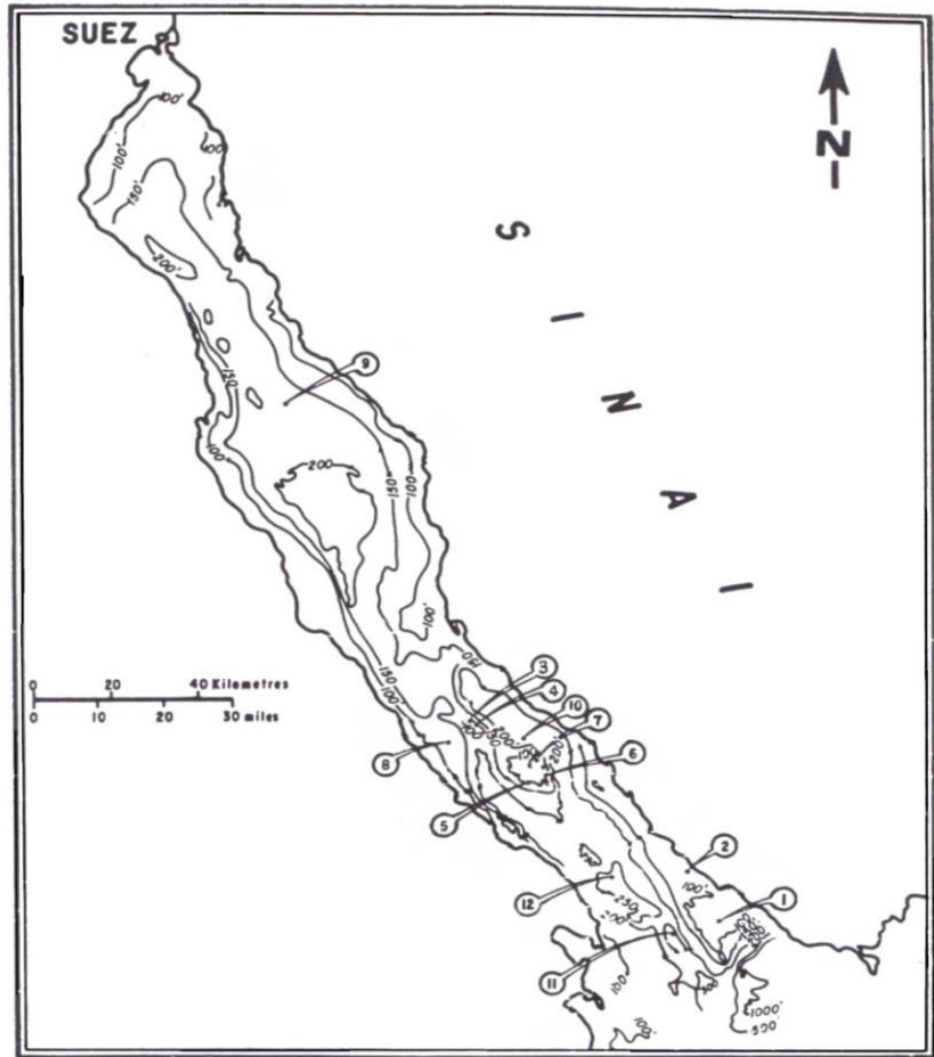

Figure (1): The location of the studied sea floor sediment samples along the Gulf of Suez.

Material was provided by the Gulf of Suez petroleum company (GUPCO) during drilling activities in a non-systematic way. Sample depths were ranging from 15 feet at station (1) to 275 feet at station (12) (Table 1).

Table (1): Sediment samples studied from Gulf of Suez and their corresponding depths in feet

\begin{tabular}{|c|c|c|c|c|c|c|c|c|c|c|c|c|}
\hline Sample & 1 & 2 & 3 & 4 & 5 & 6 & 7 & 8 & 9 & 10 & 11 & 12 \\
\hline Depth/ft. & 15 & 65 & 78 & 100 & 105 & 112 & 115 & 122 & 166 & 200 & 257 & 275 \\
\hline
\end{tabular}

Preparation of samples for diatom analysis was done according to the incineration method (Jouse et al., 1949 a and b). Diatoms mounting were undergone as described by Proschkina-Laverenko et al. (1974); the relative 
abundance of each taxon was then indicated according to Vilbaste (1994). The diatoms were grouped with respect to their salinity requirements according to Kolbe (1927) halobian system.

Diversity of diatom communities was calculated following the method of Shannon and Weaver (1949). The relative abundance is given as a percentage of the total count, while the richness of species referred to the total number of species observed at each depth. The method suggested by Maidana (1994) was used for the interpretation of water level using the percentage of planktonic species individuals in a fossil diatom sample.

Examination, identification and counting of diatoms were carried out using oil immersion lens (100x) of a binocular microscope $\left(\right.$ Tech $^{\circledR}$ Germany Instruments) fitted with a digital Canon ${ }^{\circledR}$ powershot A650 IS camera which was used to take the photomicrographs. The present work followed the system of classification proposed by Round et al. (1990).

The diatom taxa were identified according to Van Heurck (1885); Zabelinaet al. (1951); Cleve-Euler (1951, 1952, 1953 a and b); Hustedt (19271966, 1949 and 1956); Patrick and Reimer (1966 and 1975); Hendey (1974); Schoeman and Archibald (1977); Jensen (1985); Krammer and LangeBertalot (1986); Round et al. (1990) and Hasle and Syvertsen (1997).

\section{Results}

A total of 106 taxa related to 48 genera were identified from 12 sediment samples examined from the north, middle and south of the Gulf of Suez at different depths. A list of the recorded diatom taxa, their mean frequencies and the number of both genera and species at the different sampling localities were given in (Table 2). The highest species richness was recorded at $65 \mathrm{ft}$. (48 species), followed by 47 species recorded at $15 \mathrm{ft}$. The lowest species richness was recorded at $275 \mathrm{ft}$. (20 species) (Fig. 2). Similarly, the highest diversity index was found at $65 \mathrm{ft}$. (3.645) followed by that recorded at $15 \mathrm{ft}$. (3.487), the lowest being recorded at 275ft. (2.32) (Fig. 3). 
Table (2): Mean frequencies of diatoms recorded fromthe12 sediment samples (between 15 and 275ft) that were examined in the well GS 285-1, Gulf of Suez, Egypt. $\mathbf{P}=$ predominant $(50-20 \%), \mathbf{F}=$ frequent $(20-5 \%), C=$ common $(5-1 \%), \mathbf{R}=$ rare $(1-0.2 \%),+=$ noted and $-=$ not noted

\begin{tabular}{|c|c|c|c|c|c|c|c|c|c|c|c|c|}
\hline Relative abundance in stations & 1 & 2 & 3 & 4 & 5 & 6 & 7 & 8 & 9 & 10 & 11 & 12 \\
\hline $\begin{array}{l}\text { Actinocyclus cubitus G.D.Hanna \& } \\
\text { W.M.Grant. }\end{array}$ & - & - & $\mathrm{F}$ & - & $\mathrm{C}$ & - & $\mathrm{C}$ & - & - & - & $\mathrm{R}$ & - \\
\hline Actinocyclus curvatulus Janisch & - & - & $\mathrm{R}$ & $\mathrm{R}$ & - & - & - & $\mathrm{R}$ & - & - & - & $\mathrm{R}$ \\
\hline $\begin{array}{l}\text { Actinocyclus ehrenbergii var. } \\
\text { intermedia Grunn. }\end{array}$ & - & $\mathrm{R}$ & - & - & - & - & - & - & $\mathrm{R}$ & - & - & - \\
\hline $\begin{array}{l}\text { Actinoptychus marylandiscus } \\
\text { Andrews }\end{array}$ & $\mathrm{C}$ & $\mathrm{R}$ & - & $\mathrm{C}$ & $\mathrm{C}$ & - & - & $\mathrm{R}$ & - & - & - & $\mathrm{R}$ \\
\hline $\begin{array}{l}\text { Actinoptychus splendens (Shadbolt) } \\
\text { Ralfs ex Pritchard }\end{array}$ & $\mathrm{C}$ & $\mathrm{C}$ & $\mathrm{F}$ & $\mathrm{C}$ & $\mathrm{C}$ & $\mathrm{C}$ & - & - & $\mathrm{C}$ & - & - & $\mathrm{C}$ \\
\hline Actinoptychus vulgaris Schumann & $\mathrm{R}$ & $\mathrm{R}$ & $\mathrm{C}$ & $\mathrm{C}$ & $\mathrm{C}$ & - & - & - & $\mathrm{R}$ & $\mathrm{R}$ & - & $\mathrm{C}$ \\
\hline $\begin{array}{l}\text { Amphitetras cruciata Janisch \& } \\
\text { Rabenhorst }\end{array}$ & $\mathrm{R}$ & - & $\mathrm{C}$ & - & - & - & - & - & - & - & - & - \\
\hline Amphora decussata Grunow & $\mathrm{C}$ & $\mathrm{C}$ & $\mathrm{C}$ & - & - & - & - & - & $\mathrm{R}$ & $\mathrm{R}$ & - & - \\
\hline Amphora obtusa W.Gregory & $\mathrm{C}$ & $\mathrm{C}$ & - & $\mathrm{C}$ & - & - & - & - & - & $\mathrm{C}$ & - & - \\
\hline Amphora robusta Gregory & - & $\mathrm{R}$ & $\mathrm{R}$ & - & - & - & - & - & - & - & - & - \\
\hline Anomoeoneis sphaerophora E.Pfitzer & - & - & $\mathrm{R}$ & - & - & - & - & - & - & - & - & - \\
\hline Asterolampra vulgaris Greville & $\mathrm{R}$ & $\mathrm{R}$ & $\mathrm{R}$ & $\mathrm{R}$ & - & - & - & - & $\mathrm{R}$ & - & - & - \\
\hline Aulacodiscus kittonii Arnott ex Ralfs & - & - & - & - & $\mathrm{R}$ & - & $\mathrm{R}$ & - & - & - & - & - \\
\hline Aulacodiscus simplex Rattray & - & - & $\mathrm{C}$ & - & $\mathrm{R}$ & - & $\mathrm{R}$ & - & - & - & - & - \\
\hline $\begin{array}{l}\text { Aulacodiscus simulans J.W.Barker \& } \\
\text { Meakin }\end{array}$ & - & - & - & $\mathrm{R}$ & - & $\mathrm{R}$ & - & - & - & - & - & - \\
\hline Aulacoseira granulata (Ehrenberg) & $\mathrm{C}$ & $\mathrm{C}$ & - & - & - & - & - & - & - & - & - & - \\
\hline Auliscus caelatus Bailey & - & - & $\mathrm{R}$ & $\mathrm{R}$ & - & $\mathrm{R}$ & $\mathrm{R}$ & - & - & - & $\mathrm{R}$ & - \\
\hline Bacillaria paradoxa J.F.Gmelin & $\mathrm{C}$ & $\mathrm{C}$ & - & - & - & - & - & - & $\mathrm{R}$ & $\mathrm{C}$ & - & - \\
\hline Bacteriastrum hyalinum Lauder & - & - & - & - & - & - & - & - & - & $\mathrm{R}$ & - & - \\
\hline Biddulphia laevis Ehrenberg & $\mathrm{C}$ & $\mathrm{C}$ & $\mathrm{R}$ & - & - & - & - & - & $\mathrm{R}$ & $\mathrm{R}$ & $\mathrm{R}$ & - \\
\hline Biddulphia reticulata Roper & - & - & $\mathrm{R}$ & - & - & - & - & - & - & $\mathrm{R}$ & - & - \\
\hline Biddulphia tuomeyi (Bailey) Roper & - & - & $\mathrm{R}$ & - & + & - & - & + & $\mathrm{R}$ & $\mathrm{C}$ & - & + \\
\hline Campylodiscus decorus Brébisson & $\mathrm{R}$ & $\mathrm{R}$ & - & - & - & - & - & - & $\mathrm{R}$ & - & - & - \\
\hline Campylodiscus samoensis Grunow & - & $\mathrm{R}$ & - & - & - & - & - & - & - & - & $\mathrm{R}$ & $\mathrm{C}$ \\
\hline Campyloneis argus Grunow & - & $\mathrm{R}$ & - & - & - & - & - & - & - & $\mathrm{R}$ & - & - \\
\hline Chaetoceros affinis Lauder & $\mathrm{R}$ & - & - & $\mathrm{C}$ & $\mathrm{C}$ & $\mathrm{C}$ & $\mathrm{C}$ & $\mathrm{C}$ & - & - & - & $\mathrm{C}$ \\
\hline Chaetoceros coarctatus Lauder & - & - & - & - & - & $\mathrm{R}$ & - & $\mathrm{R}$ & - & - & $\mathrm{R}$ & - \\
\hline Chaetoceros compressus Lauder & $\mathrm{R}$ & - & - & - & - & $\mathrm{R}$ & - & $\mathrm{R}$ & - & - & - & - \\
\hline Chaetoceros curvisetus Cleve & - & - & - & - & - & $\mathrm{R}$ & - & - & $\mathrm{R}$ & - & - & - \\
\hline Chaetoceros decipiens Cleve & - & - & - & $\mathrm{R}$ & - & - & $\mathrm{R}$ & - & - & - & - & - \\
\hline Chaetoceros rostratus Ralfs & $\mathrm{R}$ & - & - & $\mathrm{R}$ & - & - & $\mathrm{R}$ & - & $\mathrm{R}$ & - & $\mathrm{R}$ & - \\
\hline
\end{tabular}




\begin{tabular}{|c|c|c|c|c|c|c|c|c|c|c|c|c|}
\hline Relative abundance in stations & 1 & 2 & 3 & 4 & 5 & 6 & 7 & 8 & 9 & 10 & 11 & 12 \\
\hline Chaetoceros tetrastichon Cleve & - & - & $\mathrm{R}$ & $\mathrm{R}$ & - & - & $\mathrm{R}$ & - & $\mathrm{R}$ & - & $\mathrm{R}$ & - \\
\hline $\begin{array}{l}\text { Cocconeis apiculata (Greville) } \\
\text { A.W.F.Schmidt }\end{array}$ & $\mathrm{R}$ & $\mathrm{C}$ & - & - & - & - & - & - & - & - & - & - \\
\hline $\begin{array}{l}\text { Cocconeis britannica Naegeli ex } \\
\text { Kützing }\end{array}$ & $\mathrm{R}$ & $\mathrm{C}$ & - & - & - & - & - & - & - & $\mathrm{C}$ & - & - \\
\hline Cocconeis pediculus Ehrenberg & $\mathrm{C}$ & $\mathrm{C}$ & - & - & - & - & - & - & - & $\mathrm{C}$ & - & - \\
\hline $\begin{array}{l}\text { Cocconeis placentula var. lineata } \\
\text { (Ehrenberg) van Heurck }\end{array}$ & $\mathrm{C}$ & $\mathrm{C}$ & $\mathrm{C}$ & - & - & - & - & - & - & $\mathrm{C}$ & - & - \\
\hline Cocconeis scutelliformis Grunow & $\mathrm{R}$ & $\mathrm{R}$ & - & - & - & - & - & - & - & - & - & - \\
\hline Cocconeis scutellum Ehrenberg & $\mathrm{R}$ & $\mathrm{R}$ & - & - & - & - & - & - & - & $\mathrm{R}$ & - & - \\
\hline $\begin{array}{l}\text { Coscinodiscus antiquus (Pantocsek) } \\
\text { F.Schütt. }\end{array}$ & - & - & - & $\mathrm{R}$ & - & $\mathrm{R}$ & $\mathrm{R}$ & - & - & - & - & - \\
\hline $\begin{array}{l}\text { Coscinodiscus curvatulus Grunow ex } \\
\text { A.Schmidt }\end{array}$ & - & - & $\mathrm{C}$ & $\mathrm{C}$ & $\mathrm{C}$ & - & $\mathrm{C}$ & $\mathrm{C}$ & - & - & - & $\mathrm{R}$ \\
\hline Coscinodiscus descrescens Grunow & - & - & $\mathrm{R}$ & - & - & $\mathrm{R}$ & - & $\mathrm{R}$ & - & - & - & - \\
\hline $\begin{array}{l}\text { Coscinodiscus excentricus var. } \\
\text { sublineatus Grunow }\end{array}$ & - & - & $\mathrm{R}$ & $\mathrm{R}$ & $\mathrm{R}$ & $\mathrm{R}$ & - & - & - & - & $\mathrm{R}$ & - \\
\hline Coscinodiscus granii Gough & - & - & $\mathrm{C}$ & $\mathrm{C}$ & $\mathrm{C}$ & $\mathrm{C}$ & $\mathrm{C}$ & $\mathrm{C}$ & $\mathrm{C}$ & - & $\mathrm{C}$ & - \\
\hline Coscinodiscus marginatus Ehrenberg & $\mathrm{R}$ & $\mathrm{R}$ & $\mathrm{C}$ & $\mathrm{C}$ & $\mathrm{R}$ & $\mathrm{R}$ & $\mathrm{R}$ & $\mathrm{R}$ & $\mathrm{R}$ & - & $\mathrm{R}$ & $\mathrm{R}$ \\
\hline $\begin{array}{l}\text { Coscinodiscus nodulifer } \\
\text { A.W.F.Schmidt }\end{array}$ & $\mathrm{R}$ & $\mathrm{R}$ & - & - & - & - & - & - & - & - & - & - \\
\hline Coscinodiscus radiatus Ehrenberg & $\mathrm{R}$ & $\mathrm{R}$ & $\mathrm{P}$ & $\mathrm{P}$ & $\mathrm{F}$ & $\mathrm{P}$ & $\mathrm{P}$ & $\mathrm{F}$ & $\mathrm{P}$ & - & $\mathrm{F}$ & $\mathrm{F}$ \\
\hline $\begin{array}{l}\text { Coscinodiscus Vetustissimus var. } \\
\text { Javanica Reinhold }\end{array}$ & - & $\mathrm{R}$ & - & $\mathrm{R}$ & - & $\mathrm{R}$ & $\mathrm{R}$ & $\mathrm{R}$ & - & - & - & $\mathrm{R}$ \\
\hline Cyclotella kutzingiana Thwaites & $\mathrm{C}$ & $\mathrm{C}$ & $\mathrm{F}$ & $\mathrm{F}$ & $\mathrm{F}$ & $\mathrm{F}$ & $\mathrm{F}$ & $\mathrm{F}$ & $\mathrm{F}$ & $\mathrm{C}$ & $\mathrm{C}$ & $\mathrm{R}$ \\
\hline Cyclotella ocellata Pantocsek & $\mathrm{F}$ & $\mathrm{F}$ & $\mathrm{F}$ & $P$ & $\mathrm{P}$ & $P$ & $\mathrm{~F}$ & $P$ & $\mathrm{~F}$ & $\mathrm{~F}$ & $P$ & $\mathrm{~F}$ \\
\hline Denticula tenuis Kützing & - & $\mathrm{R}$ & $\mathrm{R}$ & - & - & - & - & - & - & - & - & - \\
\hline $\begin{array}{l}\text { Dictyoneis marginata (F.W.Lewis) } \\
\text { Cleve }\end{array}$ & $\mathrm{R}$ & $\mathrm{R}$ & - & - & - & - & - & - & - & - & - & - \\
\hline $\begin{array}{l}\text { Dimerogramma minor (Gregorv) } \\
\text { Ralfs }\end{array}$ & $\mathrm{C}$ & $\mathrm{C}$ & $\mathrm{C}$ & $\mathrm{R}$ & $\mathrm{R}$ & - & $\mathrm{R}$ & $\mathrm{R}$ & $\mathrm{R}$ & $\mathrm{C}$ & $\mathrm{R}$ & $\mathrm{R}$ \\
\hline Diploneis berrupta (Kutzing) Cleve & - & $\mathrm{R}$ & $\mathrm{R}$ & - & - & - & - & - & - & $\mathrm{R}$ & - & - \\
\hline Diploneis cabro Ehrenberg & $\mathrm{R}$ & $\mathrm{R}$ & - & - & - & - & - & - & - & - & - & - \\
\hline $\begin{array}{l}\text { Diploneis diplosticta (Grunow) } \\
\text { Hustedt, }\end{array}$ & $\mathrm{R}$ & $\mathrm{R}$ & - & - & - & - & - & - & - & - & - & - \\
\hline Diploneis pseudoovalis Hustedt & - & $\mathrm{R}$ & $\mathrm{R}$ & - & - & - & - & - & - & $\mathrm{C}$ & - & $\mathrm{R}$ \\
\hline Diploneis smithii (Brébisson) Cleve & $\mathrm{R}$ & $\mathrm{C}$ & $\mathrm{R}$ & $\mathrm{R}$ & - & - & - & $\mathrm{R}$ & - & $\mathrm{C}$ & $\mathrm{C}$ & $\mathrm{R}$ \\
\hline $\begin{array}{l}\text { Diploneis smithii var. dilatata } \\
\text { (Peragallo) Terry }\end{array}$ & $\mathrm{R}$ & - & - & - & - & - & - & - & - & - & - & - \\
\hline $\begin{array}{l}\text { Diploneis suborbicularis } \\
\text { (W.Gregory) Cleve }\end{array}$ & - & - & $\mathrm{R}$ & $\mathrm{R}$ & - & - & - & - & - & - & - & - \\
\hline
\end{tabular}

Egyptian J. of Phycol. Vol. 14, 2013

-108 - 


\begin{tabular}{|c|c|c|c|c|c|c|c|c|c|c|c|c|}
\hline Relative abundance in stations & 1 & 2 & 3 & 4 & 5 & 6 & 7 & 8 & 9 & 10 & 11 & 12 \\
\hline $\begin{array}{l}\text { Diploneis weissflogii } \\
\text { (A.W.F.Schmidt) Cleve }\end{array}$ & $\mathrm{R}$ & - & - & - & - & - & - & - & - & - & - & - \\
\hline $\begin{array}{l}\text { Gomphonema olivaceum } \\
\text { (Hornemann) Brébisson }\end{array}$ & - & $\mathrm{R}$ & - & - & - & - & - & - & - & $\mathrm{R}$ & - & - \\
\hline Gomphonema truncatum Ehrenberg & - & - & - & $\mathrm{R}$ & $\mathrm{R}$ & - & - & - & - & - & - & - \\
\hline Gomphonitzschia ungeri Grunow & $\mathrm{R}$ & - & - & - & - & - & - & - & - & - & - & - \\
\hline $\begin{array}{l}\text { Grammatophora marina (Lyngbye) } \\
\text { Kützing }\end{array}$ & $\mathrm{R}$ & $\mathrm{R}$ & $\mathrm{C}$ & - & - & - & - & - & - & - & - & - \\
\hline $\begin{array}{l}\text { Gyrosigma balticum (Ehrenberg) } \\
\text { Rabenhorst }\end{array}$ & $\mathrm{R}$ & $\mathrm{R}$ & $\mathrm{R}$ & - & - & $\mathrm{R}$ & - & $\mathrm{R}$ & - & - & - & - \\
\hline Hemiaulus membranaceus Cleve & - & - & - & $\mathrm{R}$ & - & - & $\mathrm{R}$ & - & - & - & + & - \\
\hline Hyalodiscus schmidtii Frenguelli & - & - & - & - & + & - & - & - & - & - & - & + \\
\hline $\begin{array}{l}\text { Licmophora lyngbyei (Kützing) } \\
\text { Grunow ex Van Heurck }\end{array}$ & $\mathrm{R}$ & - & - & - & + & + & - & - & - & - & - & - \\
\hline $\begin{array}{l}\text { Lyrella hennedyi (W.Smith) Stickle } \\
\text { \& D.G.Mann }\end{array}$ & $\mathrm{R}$ & - & $\mathrm{R}$ & - & - & - & $\mathrm{R}$ & - & - & - & - & - \\
\hline Lyrella lyra (Ehrenberg) Karajeva & $\mathrm{R}$ & - & $\mathrm{R}$ & - & - & - & - & - & $\mathrm{R}$ & - & - & - \\
\hline Lyrella lyroides (Hendey) D.G.Mann & - & - & - & - & - & - & - & - & $\mathrm{R}$ & - & - & - \\
\hline $\begin{array}{l}\text { Mastogloia smithii Thwaites ex } \\
\text { W.Smith }\end{array}$ & - & $\mathrm{R}$ & - & - & - & $\mathrm{R}$ & $\mathrm{R}$ & $\mathrm{R}$ & $\mathrm{R}$ & - & $\mathrm{R}$ & - \\
\hline Navicula clavata Gregory & - & - & - & $\mathrm{C}$ & $\mathrm{C}$ & - & - & - & - & - & - & - \\
\hline Navicula lyra var. ehrenbergii Cleve & $\mathrm{R}$ & $\mathrm{R}$ & - & - & - & - & - & - & $\mathrm{R}$ & - & - & - \\
\hline Navicula monilifera Cleve & - & $\mathrm{R}$ & - & - & - & - & - & $\mathrm{R}$ & $\mathrm{R}$ & - & - & - \\
\hline Navicula pygmaea Kützing & $\mathrm{R}$ & $\mathrm{R}$ & - & - & - & - & - & - & - & - & $\mathrm{R}$ & - \\
\hline Navicula radiosa Kützing 1844 & $\mathrm{R}$ & $\mathrm{R}$ & $\mathrm{R}$ & - & - & - & - & - & $\mathrm{R}$ & - & - & - \\
\hline $\begin{array}{l}\text { Nitzschia closterium (Ehrenberg) } \\
\text { W.Smith }\end{array}$ & - & + & - & - & - & - & - & + & - & - & - & - \\
\hline Nitzschia lorenziana Grunow & - & + & - & - & - & - & - & - & - & - & - & - \\
\hline Nitzschia panduriformis W.Gregory & $\mathrm{R}$ & $\mathrm{R}$ & - & - & - & - & - & - & - & - & + & - \\
\hline Nitzschia sigma (Kützing) W.Smith & - & - & - & - & - & - & - & - & $\mathrm{R}$ & - & - & $\mathrm{R}$ \\
\hline Opephora martyi Héribaud-Joseph & - & $\mathrm{R}$ & - & - & - & - & - & - & - & $\mathrm{R}$ & - & - \\
\hline Paralia sulcata (Ehrenberg) Cleve & $\mathrm{F}$ & $\mathrm{F}$ & $\mathrm{F}$ & $\mathrm{P}$ & $\mathrm{F}$ & $\mathrm{F}$ & $\mathrm{F}$ & $\mathrm{F}$ & $\mathrm{F}$ & $\mathrm{F}$ & $\mathrm{F}$ & $\mathrm{F}$ \\
\hline Plagiogramma antillarum Cleve & $\mathrm{R}$ & $\mathrm{C}$ & - & - & - & - & - & - & - & $\mathrm{C}$ & $\mathrm{C}$ & - \\
\hline Plagiogramma atomus. Greville & - & - & - & - & - & - & - & $\mathrm{F}$ & - & - & - & - \\
\hline $\begin{array}{l}\text { Plagiogramma staurophorum } \\
\text { (W.Gregory) Heiberg }\end{array}$ & - & - & $\mathrm{F}$ & - & - & - & - & - & - & $\mathrm{F}$ & - & - \\
\hline $\begin{array}{l}\text { Podosira stelligera (J.W. Bailey) } \\
\text { Mann }\end{array}$ & - & - & - & $\mathrm{R}$ & - & - & $\mathrm{R}$ & - & - & - & - & - \\
\hline $\begin{array}{l}\text { Pseudo-nitzschia seriata (Cleve) } \\
\text { H.Peragallo }\end{array}$ & - & - & - & + & - & - & - & - & - & - & - & - \\
\hline Rhizosolenia cochlea J.-J.Brun & - & - & - & - & - & - & $\mathrm{R}$ & $\mathrm{R}$ & - & - & - & - \\
\hline Rhizosolenia cylindrus Cleve & - & - & - & - & - & - & $\mathrm{R}$ & $\mathrm{R}$ & - & - & - & - \\
\hline
\end{tabular}




\begin{tabular}{|l|l|l|l|l|l|l|l|l|l|l|l|l|}
\hline \multicolumn{1}{|c|}{ Taxa } & 1 & 2 & 3 & 4 & 5 & 6 & 7 & 8 & 9 & 10 & 11 & 12 \\
\hline $\begin{array}{l}\text { Relative abundance in stations } \\
\text { Kützing) Cleve }\end{array}$ & & & & & & & & & & & & \\
\hline $\begin{array}{l}\text { Stephanodiscus astraea (Ehrenberg) } \\
\text { Grunow }\end{array}$ & - & $\mathrm{R}$ & - & - & - & - & - & - & - & - & - & - \\
\hline Sticodiscus nitidus Grove \& Sturt. & - & - & $\mathrm{R}$ & - & - & - & - & - & - & - & - & - \\
\hline $\begin{array}{l}\text { Surirella fastuosa } \text { (Ehrenberg) } \\
\text { Ehrenberg }\end{array}$ & - & - & - & $\mathrm{R}$ & - & - & - & - & - & - & - & - \\
\hline $\begin{array}{l}\text { Synedra crystallina (C.Agardh) } \\
\text { Kützing }\end{array}$ & - & - & $\mathrm{R}$ & - & $\mathrm{R}$ & $\mathrm{R}$ & - & - & - & - & - & - \\
\hline $\begin{array}{l}\text { Terpsinoë americana (Bailey) } \\
\text { Grunow }\end{array}$ & $\mathrm{C}$ & $\mathrm{C}$ & - & - & - & - & - & - & - & - & - & - \\
\hline Thalassiosira decipiens Grunow & $\mathrm{R}$ & $\mathrm{C}$ & - & $\mathrm{C}$ & $\mathrm{C}$ & - & - & - & - & - & $\mathrm{C}$ & - \\
\hline $\begin{array}{l}\text { Thalassiosira eccentrica (Ehrenberg) } \\
\text { Cleve }\end{array}$ & - & - & $\mathrm{R}$ & $\mathrm{C}$ & - & $\mathrm{C}$ & $\mathrm{C}$ & - & - & - & - & - \\
\hline $\begin{array}{l}\text { Trachyneis aspera } \text { (Ehrenberg) } \\
\text { Cleve }\end{array}$ & - & - & $\mathrm{R}$ & $\mathrm{R}$ & $\mathrm{R}$ & $\mathrm{R}$ & - & - & $\mathrm{R}$ & - & - & - \\
\hline $\begin{array}{l}\text { Triceratium antediluvianum } \\
\text { (Ehrenberg) Grunow }\end{array}$ & - & - & $\mathrm{C}$ & - & $\mathrm{C}$ & $\mathrm{C}$ & - & - & - & - & - & $\mathrm{C}$ \\
\hline Triceratium balearicum Cleve & - & - & - & $\mathrm{R}$ & - & - & - & - & - & $\mathrm{C}$ & - & - \\
\hline Triceratium favus Ehrenberg & $\mathrm{R}$ & - & $\mathrm{C}$ & $\mathrm{C}$ & $\mathrm{C}$ & $\mathrm{C}$ & - & - & - & - & - & - \\
\hline $\begin{array}{l}\text { Triceratium pentacrinus } \text { (Ehrenberg) } \\
\text { Wallich }\end{array}$ & - & - & - & - & $\mathrm{C}$ & - & - & - & - & - & $\mathrm{C}$ & $\mathrm{C}$ \\
\hline Triceratium reticulum Ehrenberg & - & - & - & $\mathrm{R}$ & - & - & - & - & - & - & - & - \\
\hline Triceratium thumii A.W.F.Schmidt & $\mathrm{R}$ & - & - & - & - & - & - & - & - & - & - & - \\
\hline Triceratium. Robertianum Gréville & - & $\mathrm{R}$ & - & - & - & - & - & - & - & - & - & - \\
\hline $\begin{array}{l}\text { Trigonium arcticum (Brightwell) } \\
\text { Cleve }\end{array}$ & $\mathrm{R}$ & - & - & - & - & - & - & - & - & $\mathrm{R}$ & - & - \\
\hline
\end{tabular}




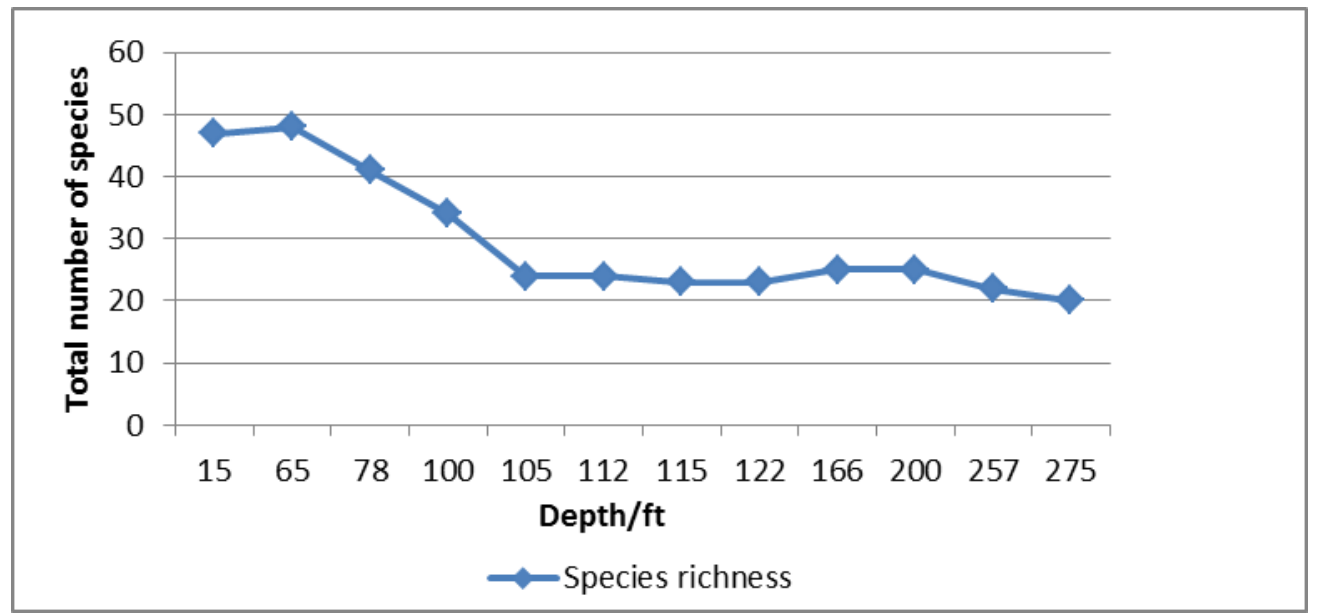

Figure (2): Species Richness (as total number of species recorded in each sampling depth) recorded in the 12 sampling sites.

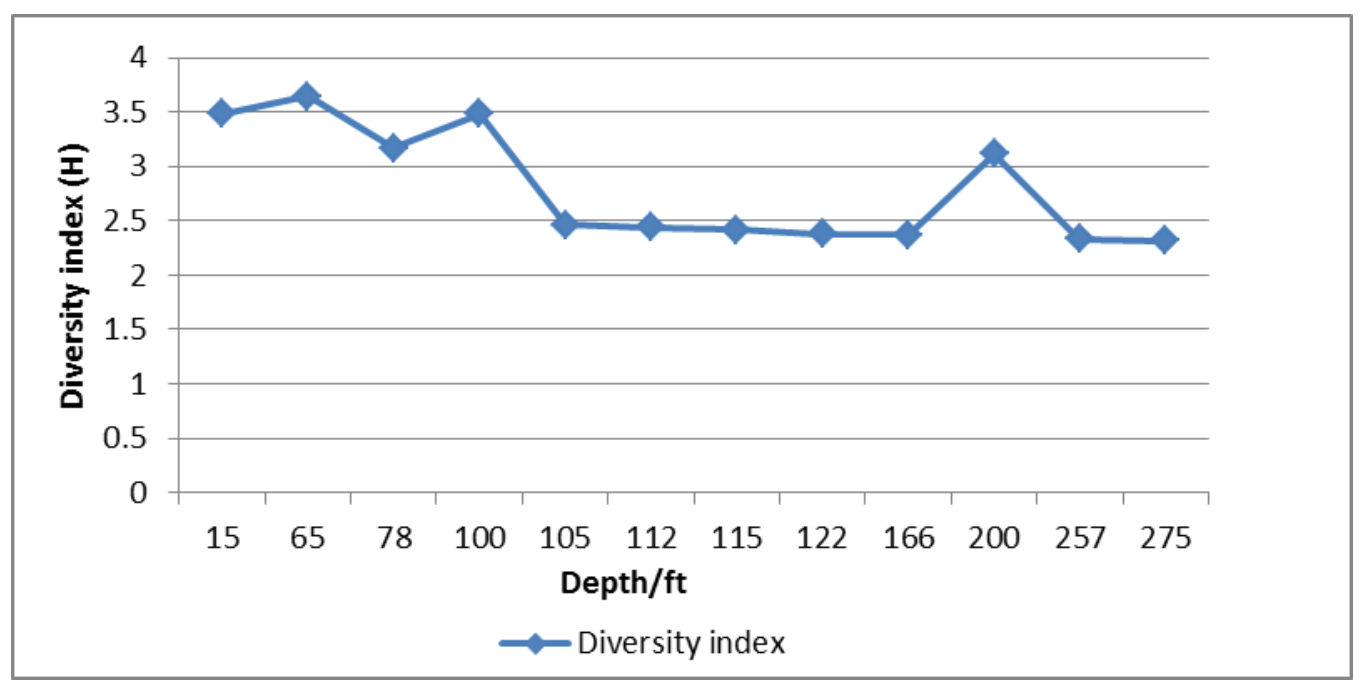

Figure (3): Diatoms Diversity Index $(\mathrm{H})$ referring to different depths in the sampling sites.

Concerning the highly qualitative and quantitative species were Paralia sulcata, Cyclotella ocellata and Coscinodiscus radiatus whereas Actinoptychus splendens, Cyclotella kutzingiana and Dimerogramma minor their number of individuals were highly recorded in some depths (Fig. 4). Paralia sulcata was 
recorded at highest abundance at 200ft; Cyclotella ocellata was highest at $122 \mathrm{ft}$, while Coscinodiscus radiatus was highest at 115 and $166 \mathrm{ft}$. The results obtained from the quantitative analyses of identified taxa enabling the discrimination between the phytoplanktonic and benthic forms (Fig. 5).

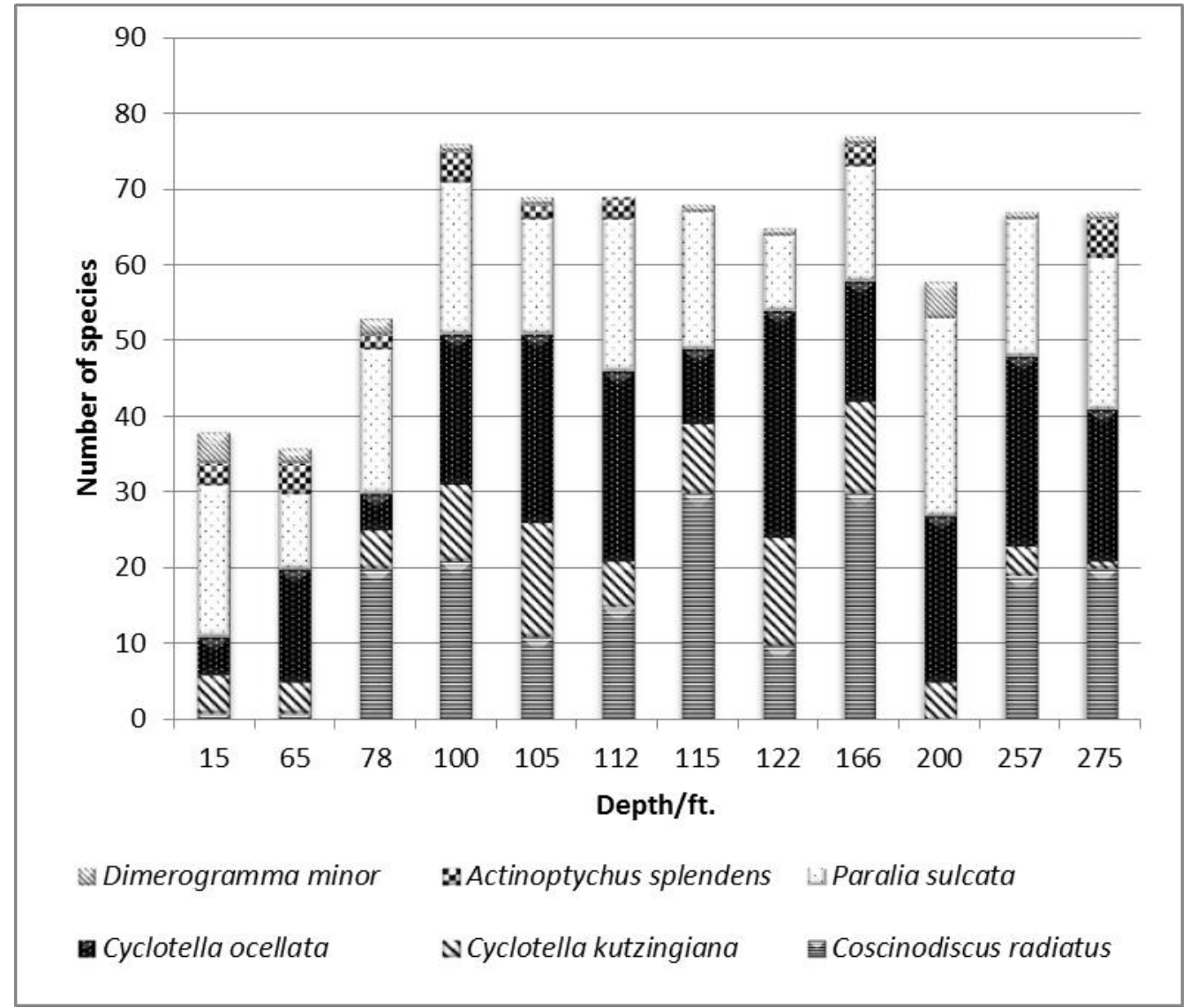

Figure (4): Distribution of the most common species (as the number of each species) recorded among the different depths. 


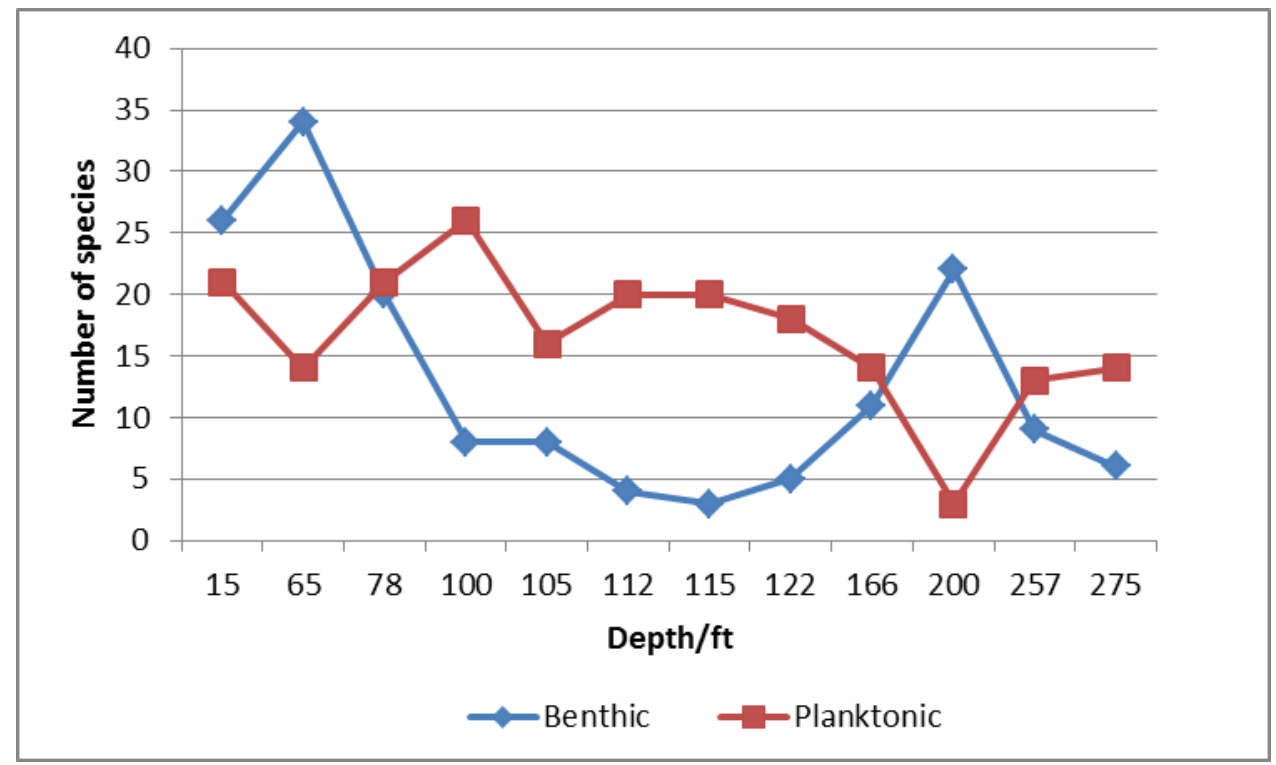

Figure (5): The recorded benthic species and phytoplankton species in relevance with depth.

It was obvious that the planktonic species were of dominance over the benthic species in almost all the depths studied, except at 15, 65 and 200ft; the highest population of phytoplanktonic species has been recorded at $100 \mathrm{ft}$, whereas the lowest was recorded at $200 \mathrm{ft}$.

An interpretation of the water level at those points in the Gulf of Suez was done through an illustration of the percentage of phytoplanktonic species in each depth. The highest and lowest points were marked; the highest percentage being at 115, 112 and 122ft, the lowest being at 200 and $65 \mathrm{ft}$ (Fig. 6).

Diatom taxa counted in all depths belonging to the marine species represent an average of $72.2 \%$ of the total number of taxa counted, while fresh water species represent $26 \%$ of the number counted for all depths studied. The investigation helps establishing the past age salinity of water at these points of the gulf. It was clear that there is an alternation in the number of fresh water and marine taxa; the number of marine species exceeded that of fresh water species at all points of study. The highest percentage of marine taxa was found at $115 \mathrm{ft}$, followed by that recorded at 112 and 122ft (Fig. 7). 
Ahmed A. El-Awamri and Hesham M. Abd El Fatah

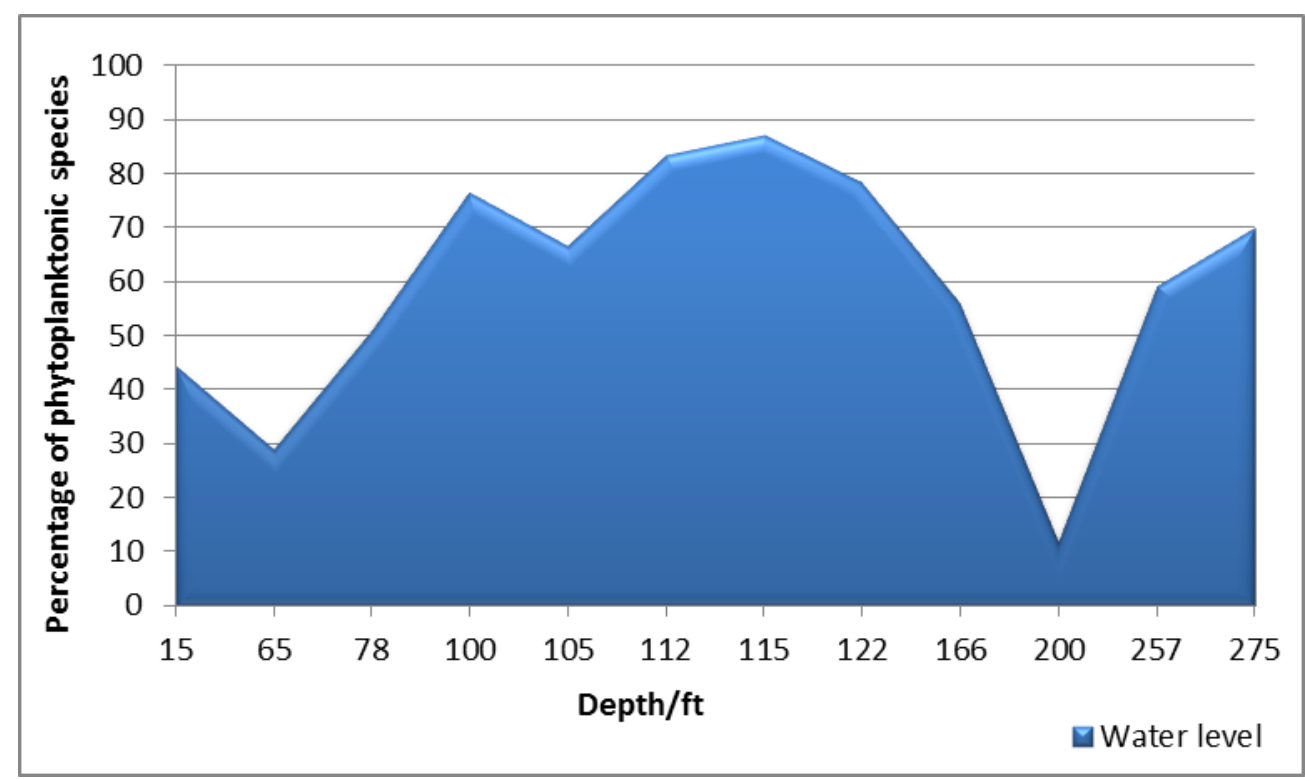

Figure (6): Interpretation of the water level in sampling sites as percentage of planktonic species in each depth.

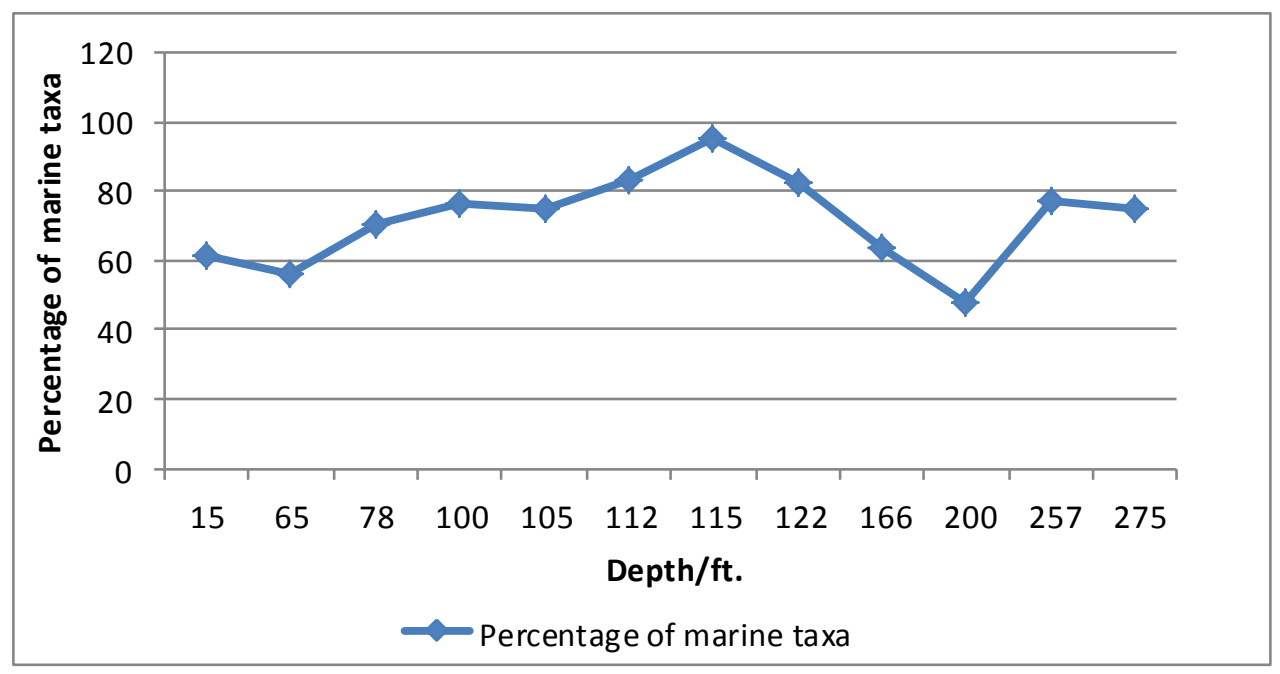

Figure (7): The percentage of marine taxa recoded at different depths along the Gulf of Suez. 


\section{Discussion}

Most of the previous investigation of the fossil diatoms in Egypt was concerned in the Fresh water bodies, only few publications dealt with marine fossil diatoms. The study surveyed the fossil diatom flora composition, their habitat preferences and their ecology from the 12 studied sites. Meanwhile, it is well known that diatoms are useful as indicators of marine, brackish and fresh water conditions and provide a valuable interpretation on environments of deposition and sea-level fluctuations (Pocknall et al., 1999, Koizumi et al., 2009, Madkour et al., 2010). On the footsteps of these previous workers, the taxa identified in these sites were traced for their ecology, salinity tolerance and habitats. It is also predictable that the high relative abundance of planktonic or tychoplanktonic species proves the existence of a true aquatic environment (Gasse, 1978).

The abundance of planktonic species in most of the studied sites (nearly 75\%) indicates a deep water environment (Andrews, 1986) accompanied by distant shores (Ali et al., 2010).

The scarcity of benthic and epiphytic taxa like Trachyneis aspera, Campyloneis argus, Triceratium robertianum and Diploneis smithii in sites (3, 4, $5,6,7,8,9,11$ and 12) confirms a deep marine environment; this result matches accordingly their location distant from the shores. Larger populations or blooms of other planktonic algae (both possibly related to higher nutrient concentrations in the water column), or increased level of suspended sediments, all of which would increase turbidity and reduce light availability to the benthic species. A reduction in the area covered by seagrass plants would also reduce habitat for benthic species, many of which are epiphytic. Increased water depth would also decrease the amount of light reaching the benthic diatom community and may result in a shift towards dominance of planktonic species (Ryu et al., 2005).

Zalat (2002) recorded Aulacoseira granulata as common in the sediments of the Suez Canal Lakes, while Paralia sulcata and Cyclotella ocellata were recorded frequent in the same lakes, the similarity between the diatom flora in the sediment of the Suez Canal Lakes and the fossil diatoms of the Gulf of Suez is nearly 55\%. Paralia sulcata (recorded predominant to frequent in almost all the studied sites) is one of the most useful diatom species for inferring past environmental conditions. Its tychoplanktonic nature must be taken into account when interpreting its usefulness as a paleoindicator of environmental change, because this species is plentiful and cosmopolitan, and more resistant to dissolution than other diatom species. It is a good marker for low-salinity; river derived water generally shallower than $100 \mathrm{~m}$ (Sancetta, 1982 and Tanimura, 1981), and is especially abundant in fine-grained, organic rich sediments (Zong, 
1997). Sancetta (1982) used high abundances of $P$. sulcata as an indicator of the shelf-slope break in the Bering Sea.

The abundance of marine taxa indicates a marine transgressional or depositional environment in those Holocene sediments (Zalat \& Vildary, 2007). The abundance of Polyhalobous taxa such as Actinocyclus curvatulus, Actinocyclus cubitus, Actinoptychus marylandiscus, Actinoptychus splendens, Auliscus caelatus, Coscinodiscus curvatulus, Coscinodiscus eccentricus, Coscinodiscus radiatus, Dimerogramma minor, Diploneis bombus, Hyalodiscus schmidtii and Plagiogramma spp. confirms indeed a typical marine depositional environment along the different sampling sites (Maidana, 1994, Tunnel $\boldsymbol{e t}$ al., 2009). The abundance of Actinocyclus spp. corresponds with a near-shore environment accompanied by an increase in the trophic conditions (Witon $\boldsymbol{e t}$ al., 2006), while the abundant and diverse assemblage of benthic diatoms (Actinoptychus spp., Hyalodiscus, Navicula spp.) indicates also shallow water conditions (Tawfic \& Krebs, 1994).

\section{References}

Abdel Salam, H. and El- Tablawy, M. (1970). Pliocene diatom assemblage from East Bakr and East Gharib Exploratory wells in Gulf of Suez. Seventh Arab Petroleum Congress, Kuwait. 57 (B-3).

Ahmed, A. A. and Pocknall, D. T. (1994). The application of palynology to exploration in the Miocene-Pliocene sequence in the Gulf of Suez. Proceedings of the EGPC, Cairo, 1: 468-481.

Aleem, A. A. (1958). A taxonomic and palaeoecological investigation of the diatom flora of the extinct Fayoum Lake (Upper Egypt). Bull. Fac. Sci. Alex. Univ. 2, Part I, 99-138; Part II, 217-240.

Ali, D. M.; El-Awamri, A. A.; Badawi, A. A. and Hamed, A. F. (2010). Fossil diatoms in Zaafarana formation, Gulf of Suez, Egypt. Inter. J. Acad. Res., 2: 91-100.

Andrews, G. W. (1986). Miocene diatoms from Richmond, Virginia. J. of Paleont., 60 (2): 497-538.

Appleby, P. G. and Oldfield, F. (1988). Radioisotope studies of recent lake and reservoir sedimentation. In Crickmore, M. J. et al. (eds.) The Use of Nuclear Techniques in Sediment Transport and Sedimentation Problems, UNESCO.

Appleby, P. G.; Nolan, P. J.; Gifford, D. W.; Godfrey, M. J.; Oldfield, F.; Anderson, N. J. and Battarbee, R. W. (1986). Dating by low background gamma counting. Hydrobiologia. 143: 21-27.

Egyptian J. of Phycol. Vol. 14, $2013 \quad$ - 116 - 
Battarbee, R. W. and Renberg. J. (1990). The Surface Water Acidification Project (SWAP) Palaeolimnology Programme. In: Palaeolimnology and Lake Acidification (R. W. Battarbee, S. J. Mason, I. Renberg, and J.F. Talling, eds), The Royal Society, London. Cambridge University Press. 1-6.

Birks, H. J. B. (1998). Numerical tools in palaeolimnology-progress, potentialities, and problems. J. Palaeolim., 20: 307-332.

Brooks, S.J; Bennion, H. and Birks, H. J. B. (2001). Tracing lake trophic history with a chironomid-total phosphorus inference model. Freshwat. Biol., 46(4): 513-533.

Cate, J.H.; Maasdam, R. and Roijackers, R. M. M. (1993). Perspectives for the use of diatom assemblages in the water management policy of Overijssel (The Netherlands). Hydrobiologia, 269/270: 335-342.

Cleve-Euler, A. (1951). Die Diatomeen von Schweden und Finnland. Teill I. Kungl Sevenska Ventensk-Akad. Handl. Band 2. No. 1, 163 pp.

Cleve-Euler, A. (1952). Die Diatomeen von Schweden und Finnland. Teill V. Kungl Sevenska Ventensk-Akad. Handl. Band 3. No. 3, 153 pp.

Cleve-Euler, A. (1953 a). Die Diatomeen von Schweden und Finnland. Teill II: Araphideae and Brachyraphideae. Kungl Sevenska VentenskAkad. Handl. Band 4. No.1, 158 pp.

Cleve-Euler, A. (1953 b). Die Diatomeen von Schweden und Finnland. Teill III: Monoraphideae and Biraphideae 1. Kungl Sevenska Ventensk-Akad. Handl. Band 4. No. 5, 255 pp.

Dixit, S. S.; Smol, J. P.; Kingston, J. C. and Charles, D.F. (1992). Diatoms: powerful indicators of environmental change. Environ. Sci. and Techno., 26: 22-33.

El-Awamri, A. A. (1984). Diatoms of El-Fayum province. Ph.D. Thesis. Fac. of Sci. Ain Shams Univ., 175 pp.

El-Shahed, A. M. (2006). Preliminary study of the diatom flora of coastal periphitic assemblages of the Red Sea and Suez Gulf, Egypt. Egypt. J. Phyco., 7(2): 185-208.

Flower, R. J.; Stickley, C.; Rose, N. L.; Peglar, S.; Fathi, A. A. and Appleby, P. G. (2006). Environmental changes at the desert margin: an assessment of recent paleolimnological records in Lake Qarun, Middle Egypt. J. Paleolimn., 35: 1-24.

Flower, R. J.; Keatings, K.; Hamdan, M.A. and Hassan, F. A. (2013). Stephanodiscus Ehr. species from Holocene sediments in the Faiyum Depression (Middle Egypt). Phytotaxa, 127 (1): 66-80.

Egyptian J. of Phycol. Vol. 14, $2013 \quad$ - 117 - 
Fritz, S. C. (1990). Twentieth-century salinity and water-level fluctuations in Devils Lake, North Dakota: Test of a diatom transfer function. Oceanography, 35: 1771- 1781.

Fritz, S. C.; Juggins, S.; Battarbee, R.W. and Engstrom, D. R. (1991). Reconstruction of past changes in salinity and climate using a diatombased transfer function. Nature, 352: 706-708.

Fritz, S. C.; Kingston, J.C. and Engstrom, D. R. (1993). Quantitative trophic reconstruction from sedimentary diatom assemblages: a cautionary tale. Freshwat. Biol., 30: 1-23.

Gasse, F. (1978). Les diatomées Holocènes d'une tourbière (4040m). d'une montagne ethiopienne: Le mont Badda. Revue Algologique, N. S., 13(2): 105-149.

Glew, J. R. (1991). Miniature gravity corer for recovering short sediment cores. J. Paleolimn. 5: 285-287.

Halim, Y. (1976). Marine biological studies in Egyptian Mediterranean waters: A review. Acta. Adriat. XVIII (2).

Hasle, G. R. and Syvertsen, E. E. (1997). Marine Diatoms. In: Identifying Marine Phytoplankton. (Tomas, C.R. Eds), pp. 5-386. San Diego: Academic Press.

Hendey, N. I. (1974). A revised check-list of the British marine diatoms. Journal of the Marine Biological Association of the United Kingdom, 54: 277-300.

Hustedt, F. (1927-1966). Die Kieselalgen Deutschlands, Oester - reichs und der Schweiz Rabenhorst' Kryptogamenflora, VII. Akademisch Verlagsgesellschaft Leipzig. (Cited in Sterrenburg, F.A.S., (1994).

Hustedt, F. (1949). Süsswasser-Diatomeen. Inst. Parcs Natl. Congo Belge. Explor. Parc Natl. Albert, 8: 199 pp.

Hustedt, F. (1956). Kieselalgen (Diatomeen). Stuttgart, Fränckh' sche Verlagshandlung, W.Keller and Co., 70 pp.

Jensen, N. G. (1985). The Pennate Diatoms. A translation of Hustedt's "Die Kieselalgen, 2. Teil.” Koeltz Scientific Books, Koenigstein, 918 pp.

Jouse, A.P.; Kicelov, I.A.: Proschkina-Laverenko, A.I. and Sheshykova, V.S. (1949 a). Diatomical Analysis. Vol. 2. Publ. "Geol. Liter". Leningrad, pp. 212-213.

Jouse, A.P.; Proschkina-Laverenko, A.I. and Sheshykova, V.S. (1949 b). Diatomical Analysis. Vol. 1. Publ. "Geol.Liter". Leningrad, 239 pp. 
Kashima, K. (1994). Diatom assemblages from lake sediment samples in Lake Nakaumi and Lake Shinji, coastal lagoons in Japan: an attempt to reconstruct a sensitive high - resolution record of environmental change. In: Proceedings of the $13^{\text {th }}$ International Diatom Symposium. D. Marino and M. Montresor (eds.). Biopress Limited, Bristol, pp. 101-106.

Koizumi, I.; Sato, M. and Matoba, Y. (2009). Age and significance of Miocene diatoms and diatomaceous sediments from northeast Japan. Palaeogeography, Palaeoclimatology, Palaeoecology, 272: 85-98.

Kolbe, R. W. (1927). Zur Okuologie, Morphologie und Systematik der BrackWasser-Diatomeen. Pflanzenf., 7: 1-146.

Krammer, K. and Lange-Bertalot, H. (1986). Bacillariophyceae.1.Teil: Naviculaceae. In: Süsswasserflora von Mitteleuropa. Band 2/1. H. Ettl; J. Gerloff; H. Heynig and D. Mollenhauer (eds.).Gustav Fisher Verlag, Stuttgart, 876 pp.

Laušević, R. and Cvijan, M. (1994). Planktonic diatoms in the Vlasinko Jezero reservoir, Serbia (Yugoslavia). In: Proceedings of the $13^{\text {th }}$ International Diatom Symposium. D. Marino and M. Montresor (eds.). Biopress Limited, Bristol, pp. 295-309.

Madkour, F. F.; El-Sherbiny, M. M. and Aamer, M. A. (2010). Phytoplankton population along certain Egyptian coastal regions of the Red Sea. Egypt J. Aquat. Biol. \& Fish., 14(2): 95-109.

Maidana, N. I. (1994). Fossil diatoms from Salinas Del Bebedero (San Luis, Argentina). Diatom Res., 9(1): 99-119.

Martin-Jézéquel, V.; Hildebrand, M. and Brzezinski, M. A. (2000). Silicon metabolism in diatoms implications for growth. J. Phycol., 36: 821-840.

Patrick, R. and Papavage, D. M. (1994). The value of species as indicators of water quality. Proceedings of the Academy of Natural Sciences of Philadelphia, 145: 55-92.

Patrick, R. and Reimer, C. W. (1966). The diatoms of the United States (Exclucive of Alaska and Hawaii). 1: Fragilariaceae, Eunotiaceae, Achnanthaceae, and Naviculaceae. Monogrs. Acad. Sci. Philad. 13: $688 \mathrm{pp}$.

Patrick, R. and Reimer, C. W. (1975). The diatoms of the United States (Exclucive of Alaska and Hawaii).2, Part 1: Entomoneidaceae, Cymbellaceae, Gomphonemaceae, and Epithemiaceae. Monogrs. Acad. Sci. Philad. 13: 213 pp. 
Pennington, W.; Cambray, R. S. and Fisher, E. M. (1973). Observations on lake sediments using fallout as a tracer. Nature, 242: 324-326.

Pocknall, D. T.; Krebs, W. N.; Tawfic, E. and Ahmed, A. A. (1999). Pliocene climate and depositional environments, Gulf of Suez, Egypt: Evidence from palynology and diatoms; Wrenn, J.H., Suc, J.-P. and Leroy, S. A. G. (eds), The Pliocene: Time of Change; American Association of Stratigraphic Palynologists Foundation, 163-171.

Proschkina-Laverenko, A.I.; Gleser, S.I.; Jouse, A.P.; Makarova, I.V. and Schesschykova-Poretzaja, V.S. (1974). The Diatoms of USSR. Fossil and Recent. I. Publ. House"Sov. Nauke.", Leningrad. Bronch., 372 pp.

Renberg, I. (1990). A procedure for preparing large sets of diatom slides from sediment cores. J. Paleolimn., 4: 87-90.

Rigual-Hernández, A. S.; Bárcena, M. A.; Jordan, R. W.; Sierro, F. J.; Flores, J. A.; Sebastian Meier, K. J.; Beaufort, L. and Heussner, S. (2013). Diatom fluxes in the NW Mediterranean: evidence from a 12year sediment trap record and surficial sediments. J. Plankton Res., 35 (5): 1109-1125.

Round, F. E.; Crawford, R.M. and Mann, D.G. (1990). The diatoms: biology and morphology of the genera. Cambridge University Press, Cambridge, 747 pp.

Ryu, E.; Yi, S. and Lee, S. (2005). Late Pleistocene-Holocene paleoenvironmental changes inferred from the diatom record of the Ulleung Basin, East Sea (Sea of Japan). Marine Micropaleontology, 55: 157-182.

Sadek, A. (1978). Nannofossils and diatoms from some Pliocene sediments of the North western Desert Salum area Egypt News Jahrb. Geol. Und Palaontol. Monatsh, 5: 307-313.

Sancetta, C. (1982). Distribution of diatom species in surface sediments of the Bering Sea and Okhotsk Seas. Micropaleontology, 28: 221-257.

Schoeman, F. R and Archibald, R. E. M. (1977). The Diatom Flora of Southern Africa. No. 3, September 1977. CSIR Special Report Wat 50. No pagination; series of plates with text. National institute for water research, CSIR. Pretoria, 61 pp.

Shannon, C.E. and Weaver, W. (1949). The Mathematical Theory of Communications. Illinois Univ. Press, London, 125 pp.

Silva-Benavides, A. M. (1996). The use of water chemistry and benthic diatom communities for qualification of a polluted tropical river in Costa Rica. Rev. Biol. Trop., 44(2A): 395- 416.

Egyptian J. of Phycol. Vol. 14, $2013 \quad \mathbf{- 1 2 0}$ - 
Sukhanova, I. N. (1969). Some data on the phytoplankton of the Red Sea and the Western Gulf of Aden. Oceanology, Wash. (Transl. of Okeanologiya, Mosk.), 9: 243-247.

Taffs, K. H. (2001). Diatoms as indicators of wetland salinity in the upper South East of South Australia. Holocene, 11(3): 281-290.

Tanimura, Y. (1981). Late Quaternary diatoms of the Sea of Japan. Sci. Rep. Tohoku Univ., Ser. 251: 1 - 36.

Tawfic, E. and Krebs, W. N. (1994). Age and paleoenvironmental significance of diatom recovery from the Zeit Formation and "PostZeit" section, Gulf of Suez, Egypt. Proceedings of the EGPC, Cairo, November 1994, 1: 528-543.

ter Braak, C. J. F. (1986). Canonical correspondence analysis: A new eigenvector method for multivariate direct gradient analysis. Ecology, 67: 1167-1179.

Tunnel, J. W.; Felder, D. L. and Earle, S. A. (2009). Gulf of Mexico origin, waters and biota: Biodiversity. Texas A and M University Press, 1312pp.

Van Dam, H. (1993). Diatom investigation. In: Proceedings of the $12^{\text {th }}$ International Diatom Symposium. H. Van Dam (ed.). Kluwer Academic Publishers, Dordrecht/ Boston/London, 540 pp.

Van Heurck, H. (1885). Synopsis des Diatomées de Belgique. Texte. pp. 1235. Anvers: Mtin. Brouwers and Co.

Vilbaste, S. (1994). The epiphytic and microphytobenthic diatoms in Estonian coastal waters (the Baltic Sea). In: Proceedings of the $13^{\text {th }}$ International Diatom Symposium.D. Marino and M. Montresor (eds.). Biopress Limited, Bristol, pp. 259-269.

Witon, E.; Malmgren, B.; Witkowski, A. and Kuijpers, A. (2006). Holocene marine diatoms from the Faeroe Islands and their paleoceanographic implications. Palaeogeography, Palaeoclimatology, Palaeoecology, 239: 487-509.

Wright, H. E. (1980). Cores of soft lake sediment. Boreas, 9: 107-114.

Zabelina, M. M.; Kicelov, I. A.; Proschkina-Laverenko, A. I. and Scheshykova, V. S. (1951). The Freshwater Algae of USSR. 4. Bacillariophyta. Publ. "Sov. Nauk." Moscow, 619 pp.

Zalat, A. A. (1995). Diatoms from the Quaternary sediments of the Nile Delta, Egypt, and their palaeoecological significance. J. of African Earth Sci., 20(2): 133-150. 
Zalat, A. A. (1997). Distribution of Holocene diatoms and silicoflagellates in bottom sediments of the Lake Timsah, Suez Canal area, Egypt. Egypt. J. Geol., 41(1): 103-128.

Zalat, A. A. (2002). Distribution and origin of diatoms in the bottom sediments of the Suez Canal Lakes and adjacent areas, Egypt. Diatom Res., 17(1): 243-266.

Zalat, A. A. and Vildary, S. S. (2007). Environmental change in Northern Egyptian Delta Lakes during the Late Holocene, based on diatom analysis. J. Paleolimn., 37: 273-299.

Zong, Y., (1997). Implications of Paralia sulcata abundance in Scottish isolation basins. Diatom Res., 12: 125-150.

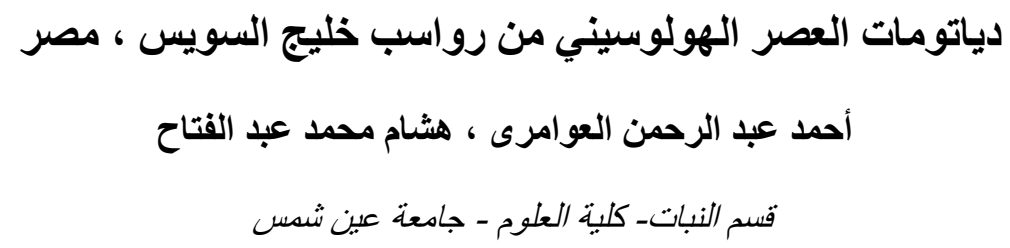

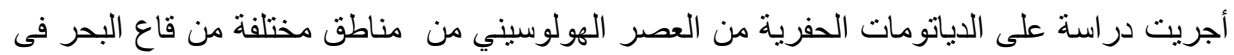

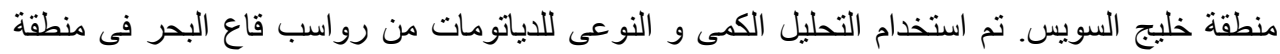

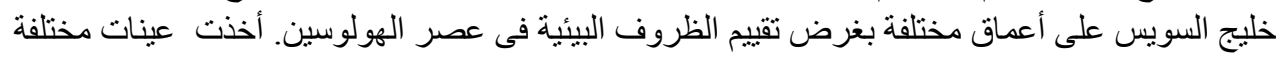

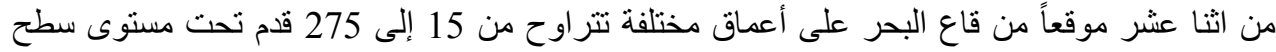

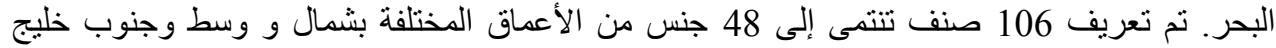

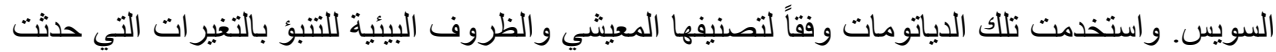
في نوعية المياه خلال تلك الحقبة الزمنية (الهولوسين). 

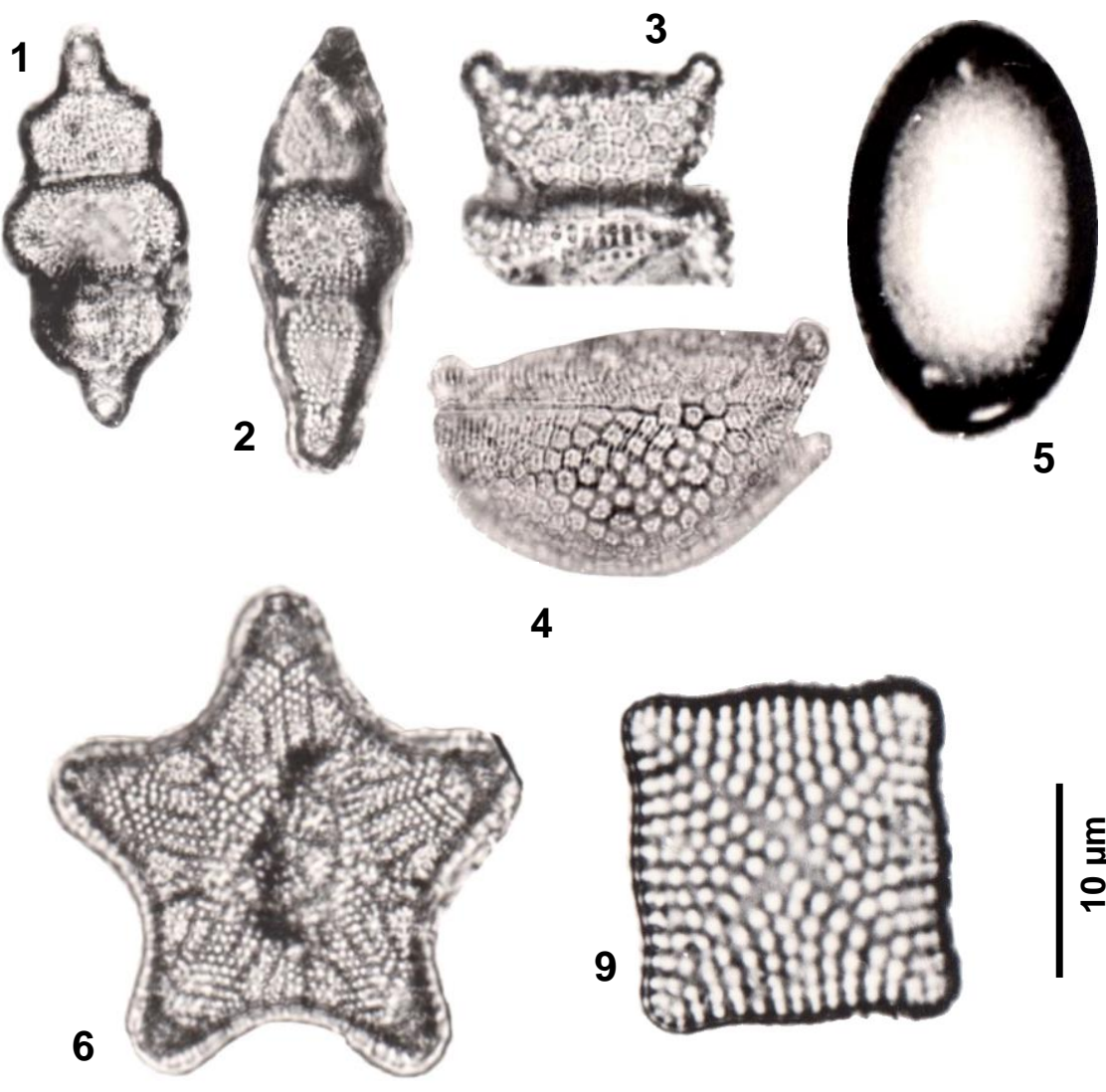

4
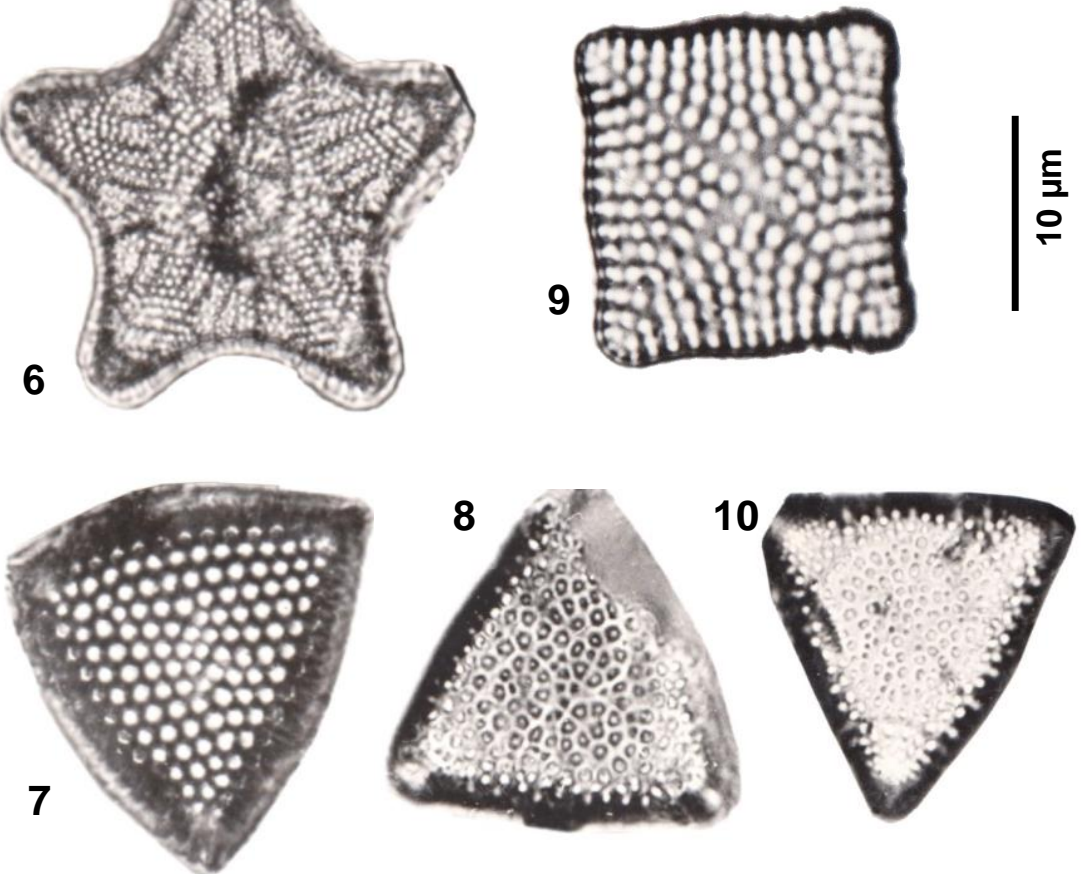

Plate (1): $1 \& 2$ Biddulphia tuomeyi (Bailey) Roper, 3 \& 4. B. reticulata Roper, 5. B. laevis Ehrenberg, 6. Triceratium pentacrinus (Ehrenberg) Wallich, 7. T. thumii A.W.F.Schmidt, 8. T. favus Ehrenberg, 9. Amphitetras cruciata Janisch \& Rabenhorst, 10. Trigonium arcticum (Brightwell) Cleve. (Scale bar $=10 \mu \mathrm{m}$ ). 

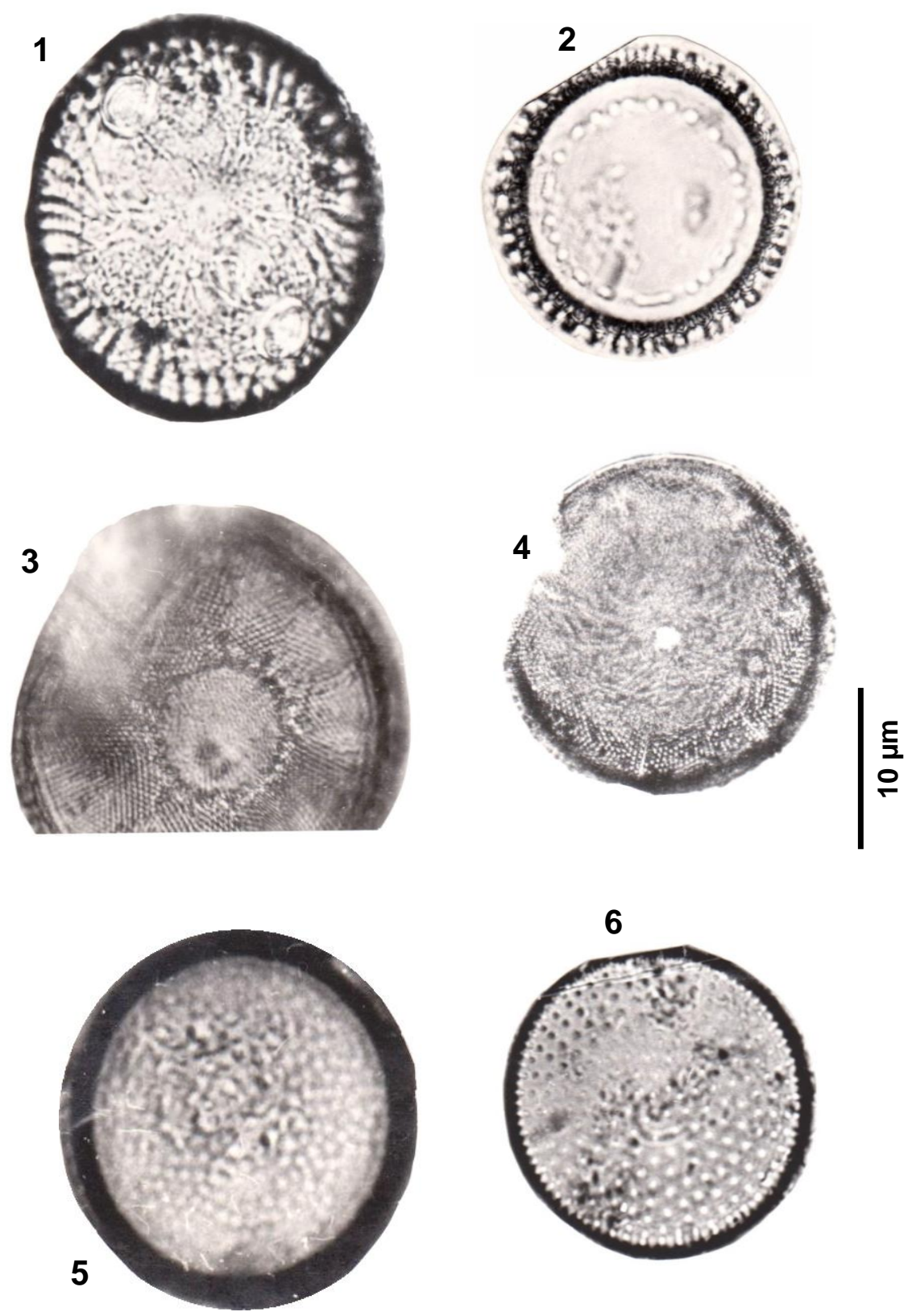

Plate (2): 1. Auliscus caelatus Bailey, 2. Paralia sulcata (Ehrenberg) Cleve, 3. Podosira stelligera (J.W. Bailey) Mann, 4. Aulacodiscus simplex Rattray, 5. Coscinodiscus excentricus var. sublineatus Grunow, 6. Thalassiosira decipiens Grunow. (Scale bar $=10$ $\mu \mathrm{m})$ 

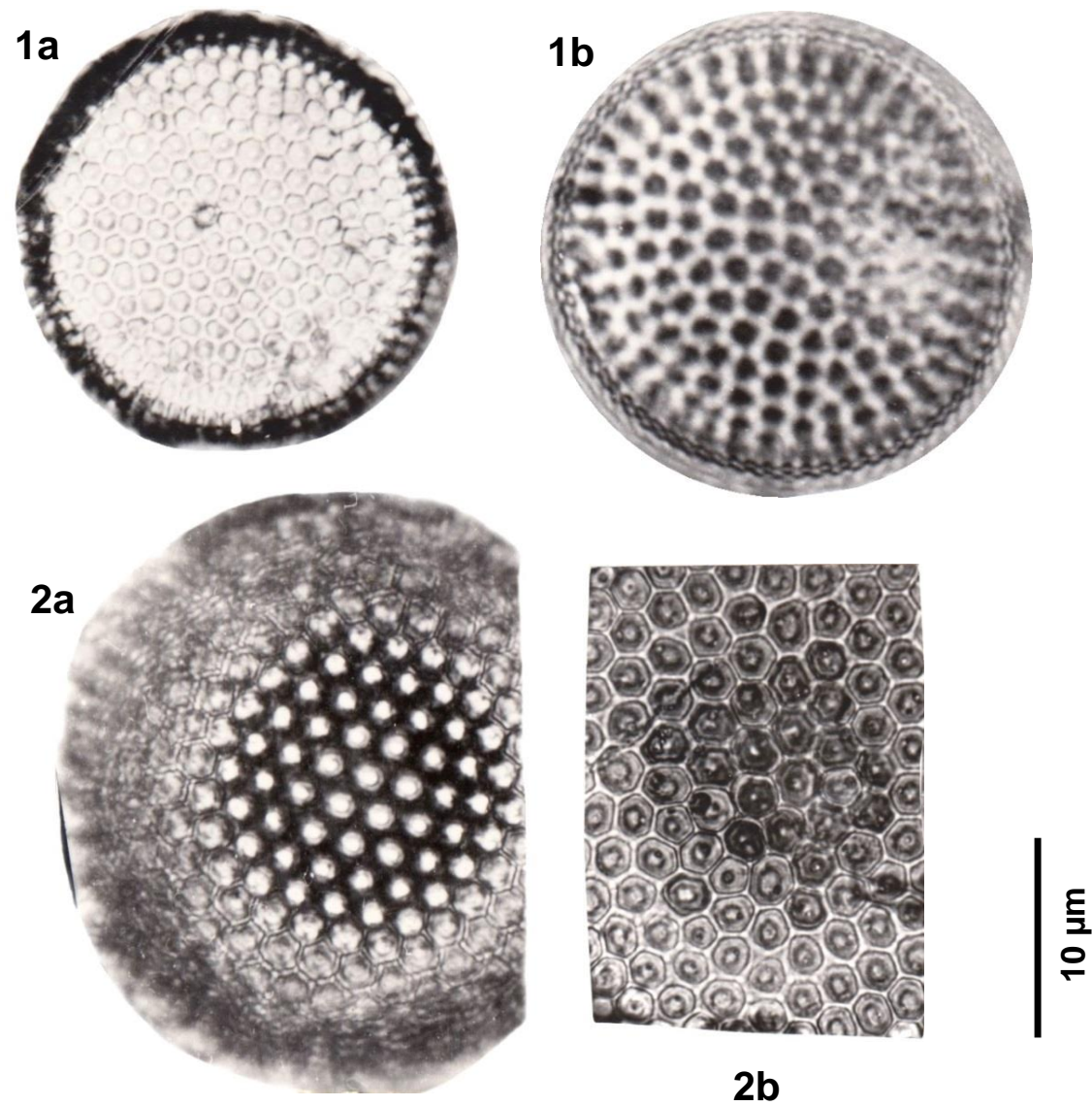

$2 b$
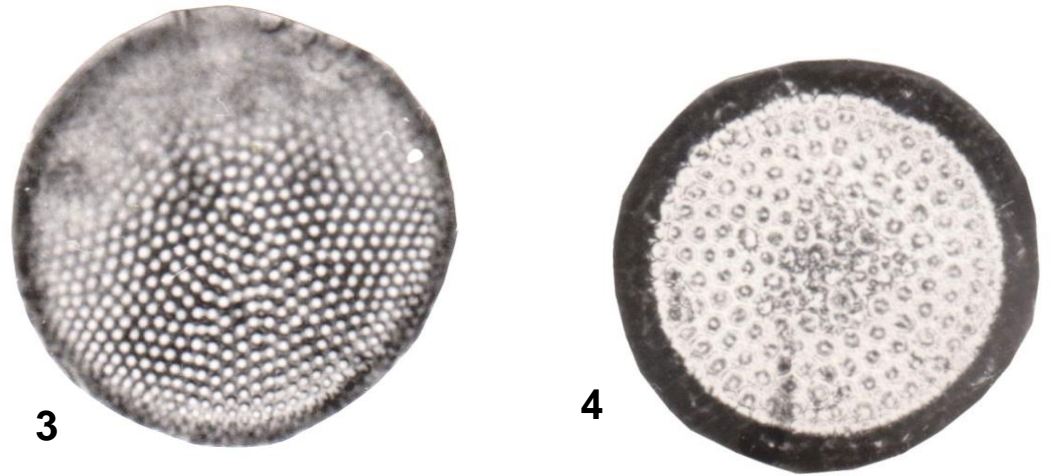

Plate (3): 1. a \& b Coscinodiscus radiatus Ehrenberg, 2. a \& b C. nodulifer A.W.F.Schmidt, 3. C. granii Gough, 4. C.curvatulus Grunow ex A.Schmidt. $($ Scale bar = $10 \mu \mathrm{m})$ 

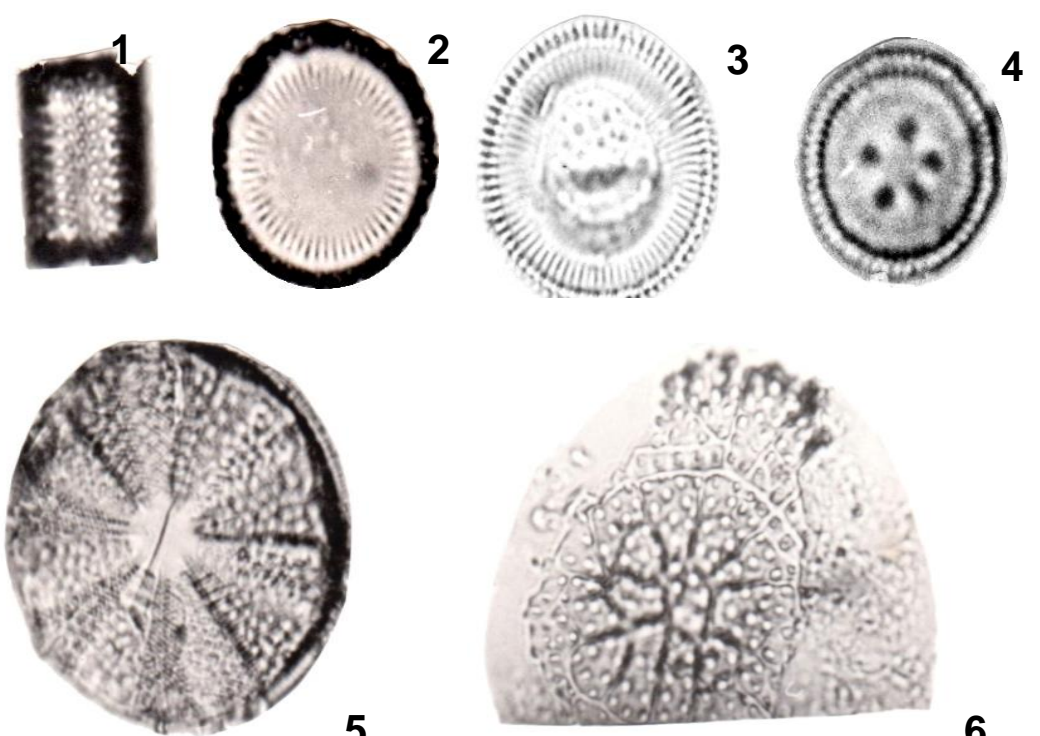

5

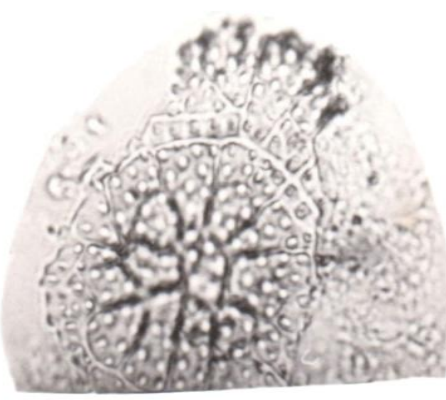

6

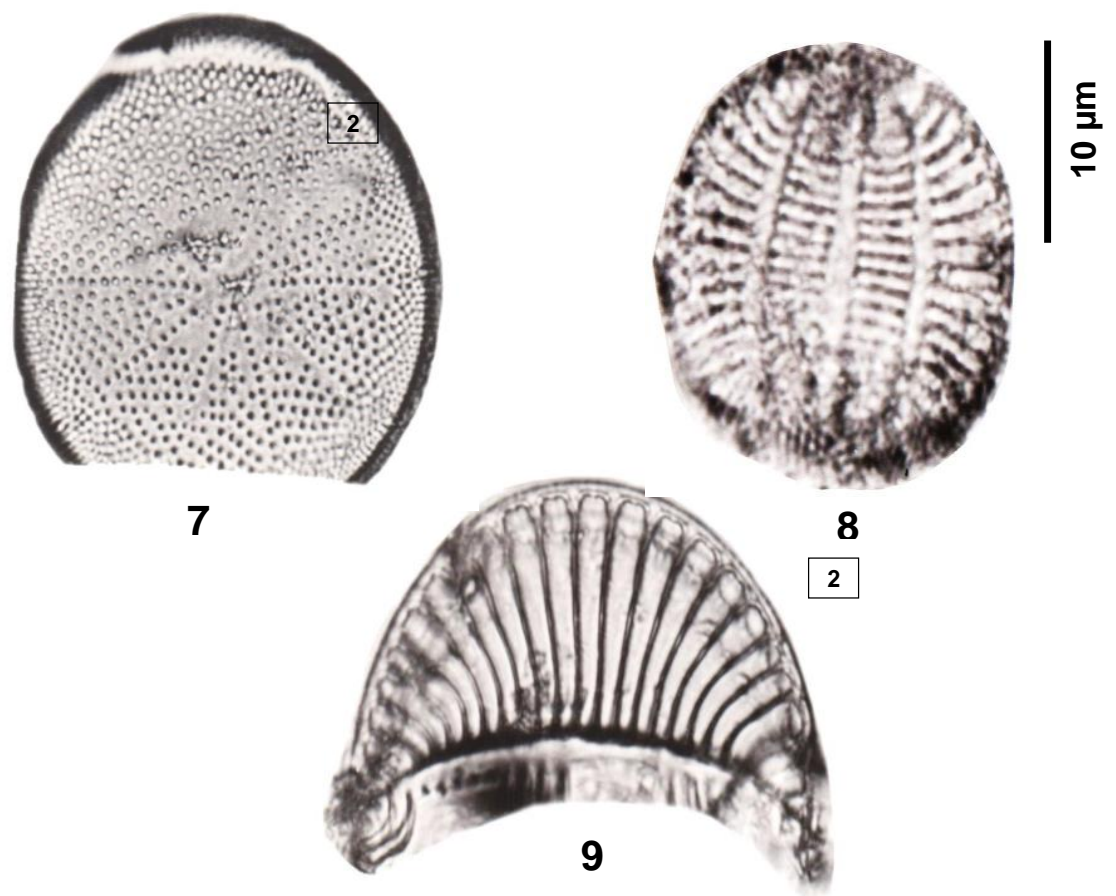

Plate (4): 1. Aulacoseira granulata (Ehrenberga, 2. Stephanodiscus astraea (Ehrenberg) Grunow, 3. Cyclotella kutzingiana Thwaites, 4. C. ocellata Pantocsek, 5. Actinoptychus marylandiscus Andrews, 6. Asterolampra vulgaris Greville, 7. Actinocyclus ehrenbergii var. intermedia Grunn., 8. Campylodiscus samoensis Grunow, 9.C. decorus Brébisson. $($ Scale bar $=10 \mu \mathrm{m})$. 

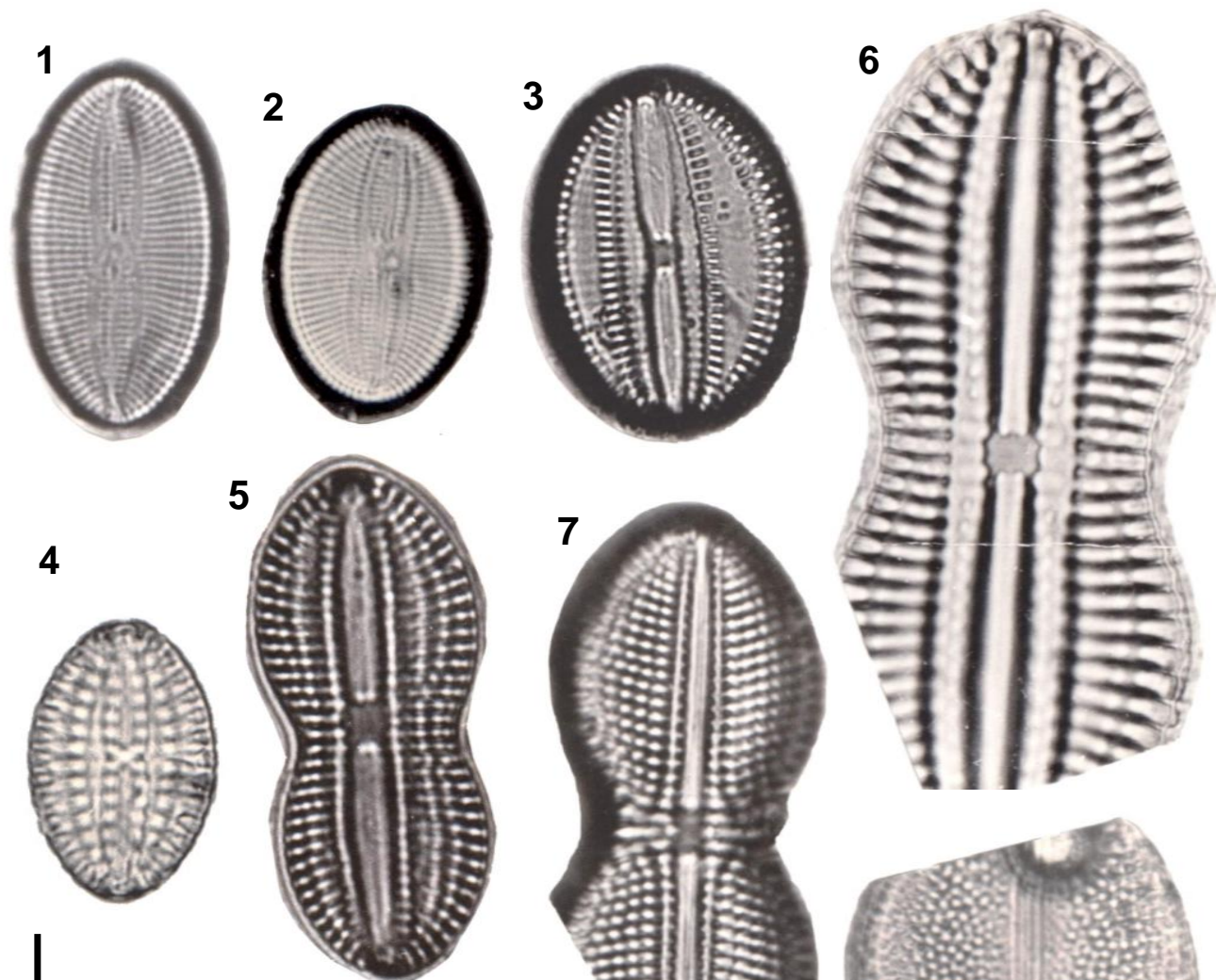

혹
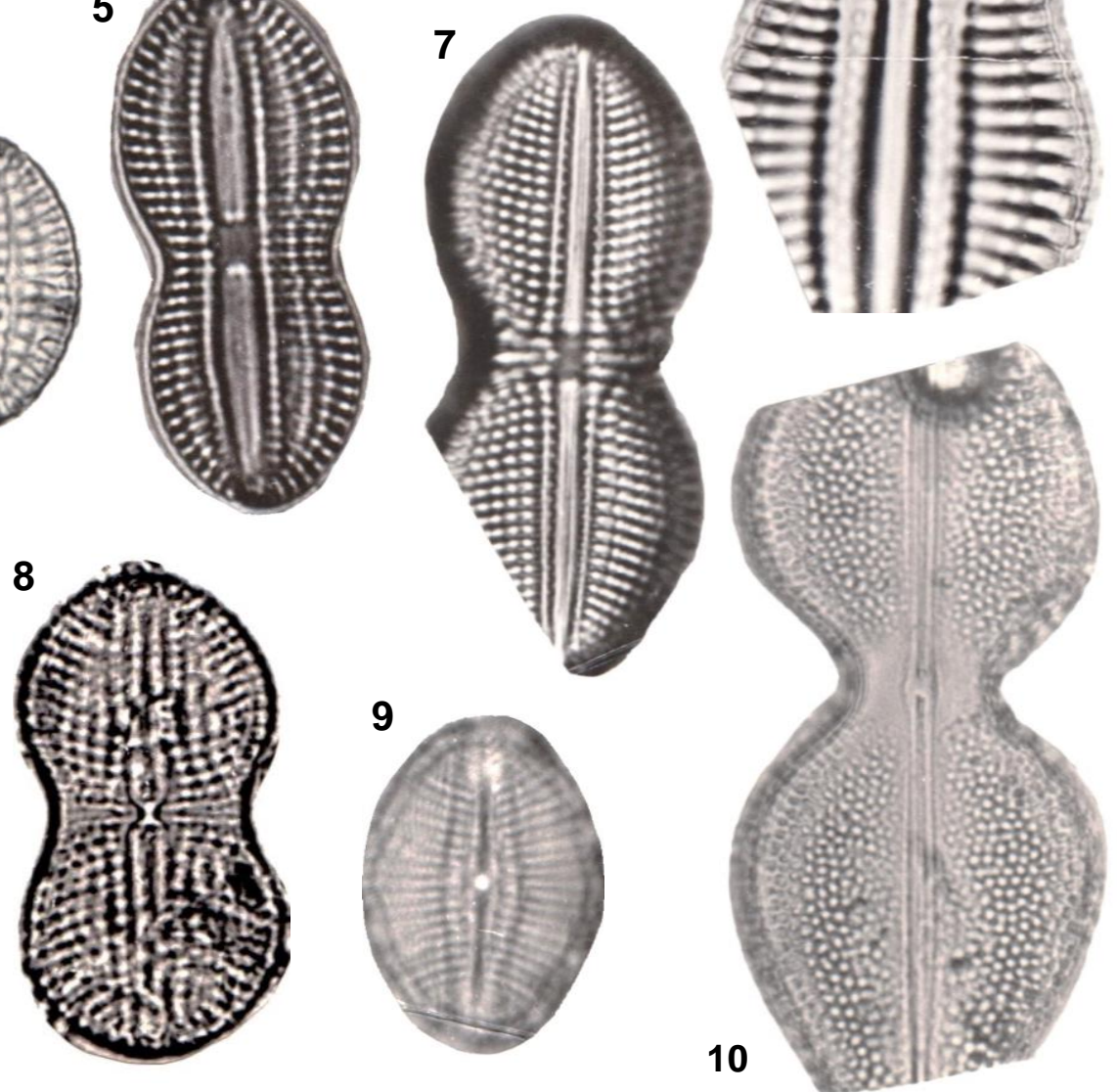

Plate (5): 1\& 2. Diploneis smithii (Brébisson) Cleve, 3. D. suborbicularis (W.Gregory) Cleve, 4. D. smithii var. dilatata (Peragallo) Terry, 5 \& 6. D. cabro Ehrenberg, 7. D. weissflogii (A.W.F.Schmidt) Cleve , 8. D. diplosticta (Grunow in Schmidt et al.) Hustedt, 9. D. pseudoovalis Hustedt, 10. Dictyoneis marginata (F.W.Lewis) Cleve. (Scale bar $=$ $10 \mu \mathrm{m})$.

Egyptian J. of Phycol. Vol. 14, 2013

$-127-$ 

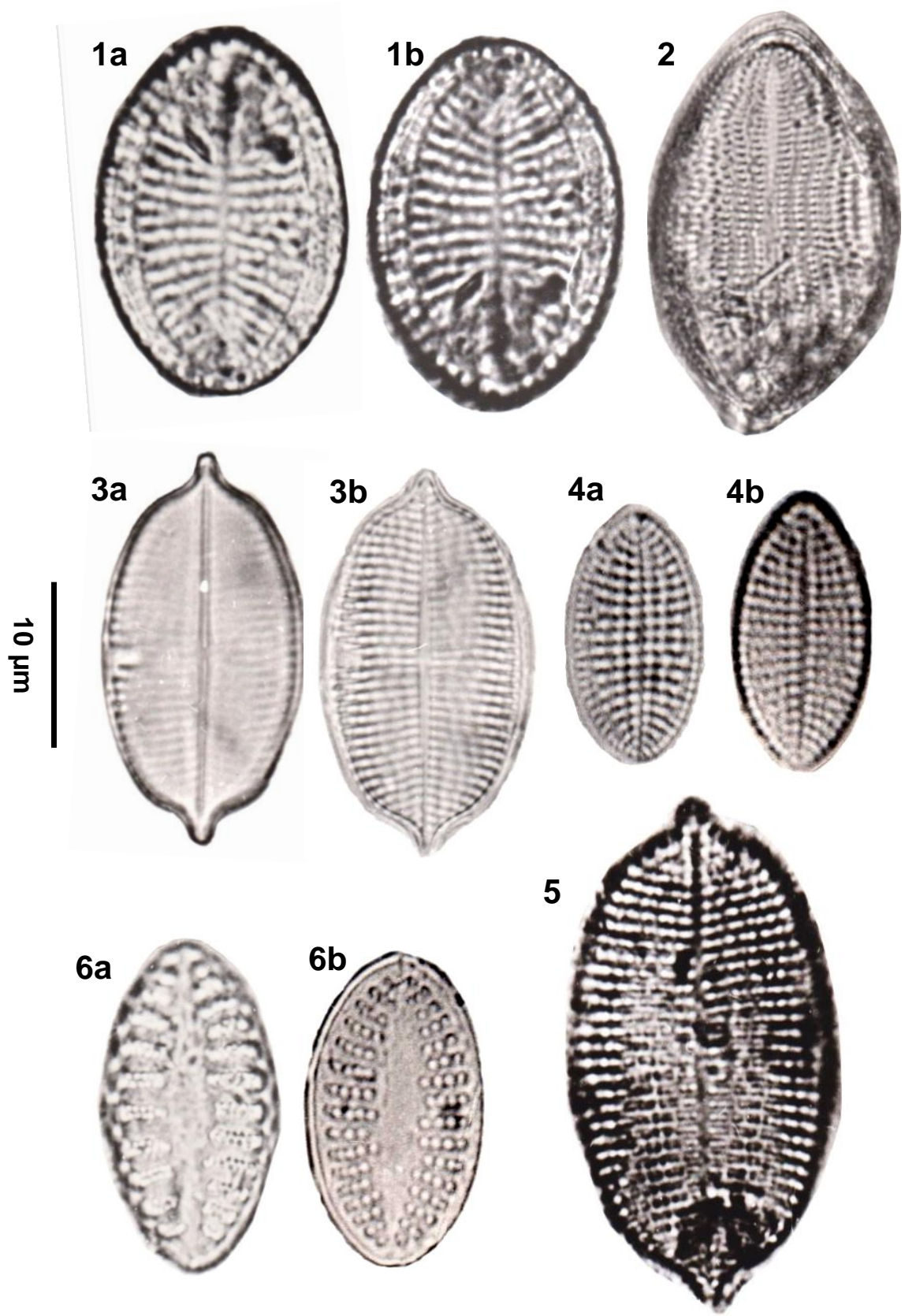

Plate (6): 1 a \& b. Cocconeis scutelliformis Grunow, 2. C. placentula var. lineata (Ehrenberg) van Heurck, 3 a \& b. C. apiculata (Greville) A.W.F.Schmidt, 4 a \& b. C. pediculus Ehrenberg, 5. C. apiculata (Greville) A.W.F.Schmidt, 6 a \& b. Campyloneis argus Grunow. (Scale bar $=10 \mu \mathrm{m}$ ). 
1

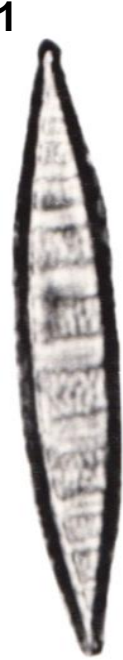

2

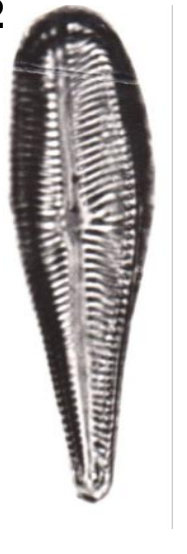

3

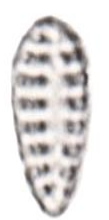

5

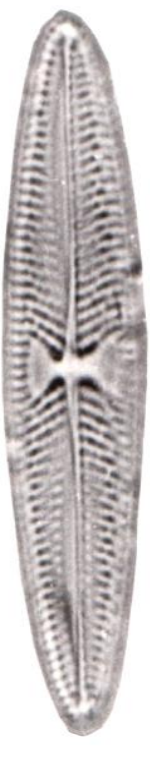

6

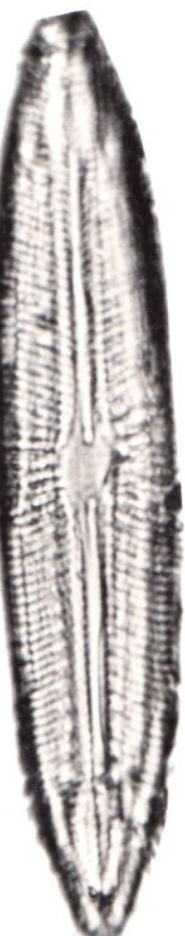

9
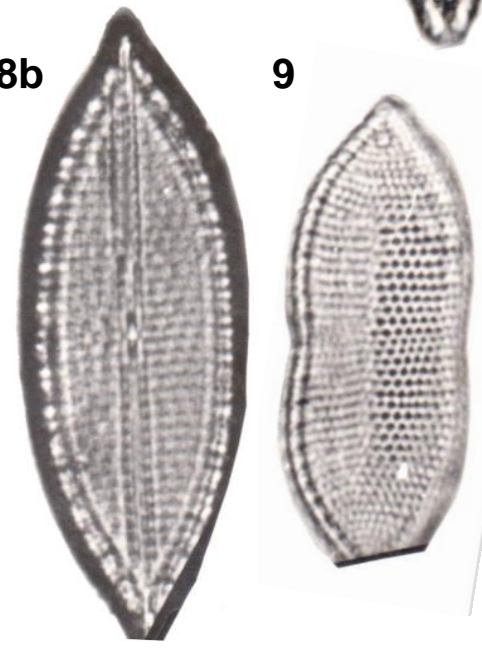
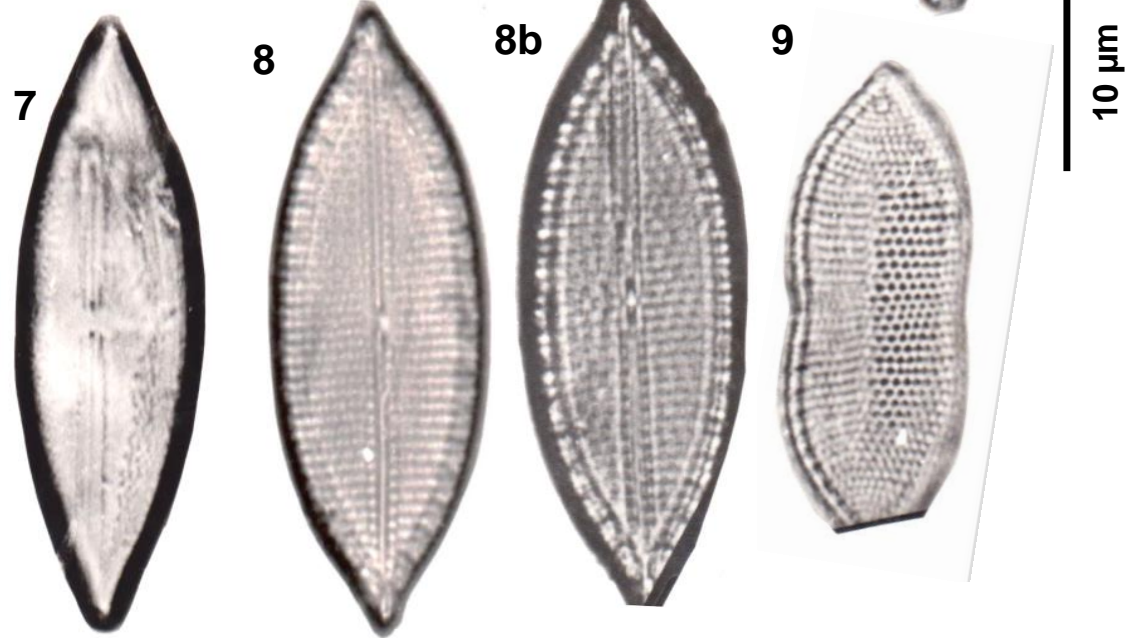

톡

Plate (7): 1. Denticula tenuis Kützing, 2. Gomphonema truncatum Ehrenberg, 3. Opephora martyi Héribaud-Joseph, 4. Gomphonitzschia ungeri Grunow, 5. Trachyneis aspera (Ehrenberg) Cleve, 6. Scoliotropis latestriata (Brébisson ex Kützing) Cleve, 7. Anomoeoneis sphaerophora E.Pfitzer, 8 a \& b. Mastogloia smithii Thwaites ex W.Smith, 9. Nitzschia panduriformis W.Gregory. (Scale bar $=10 \mu \mathrm{m})$ 


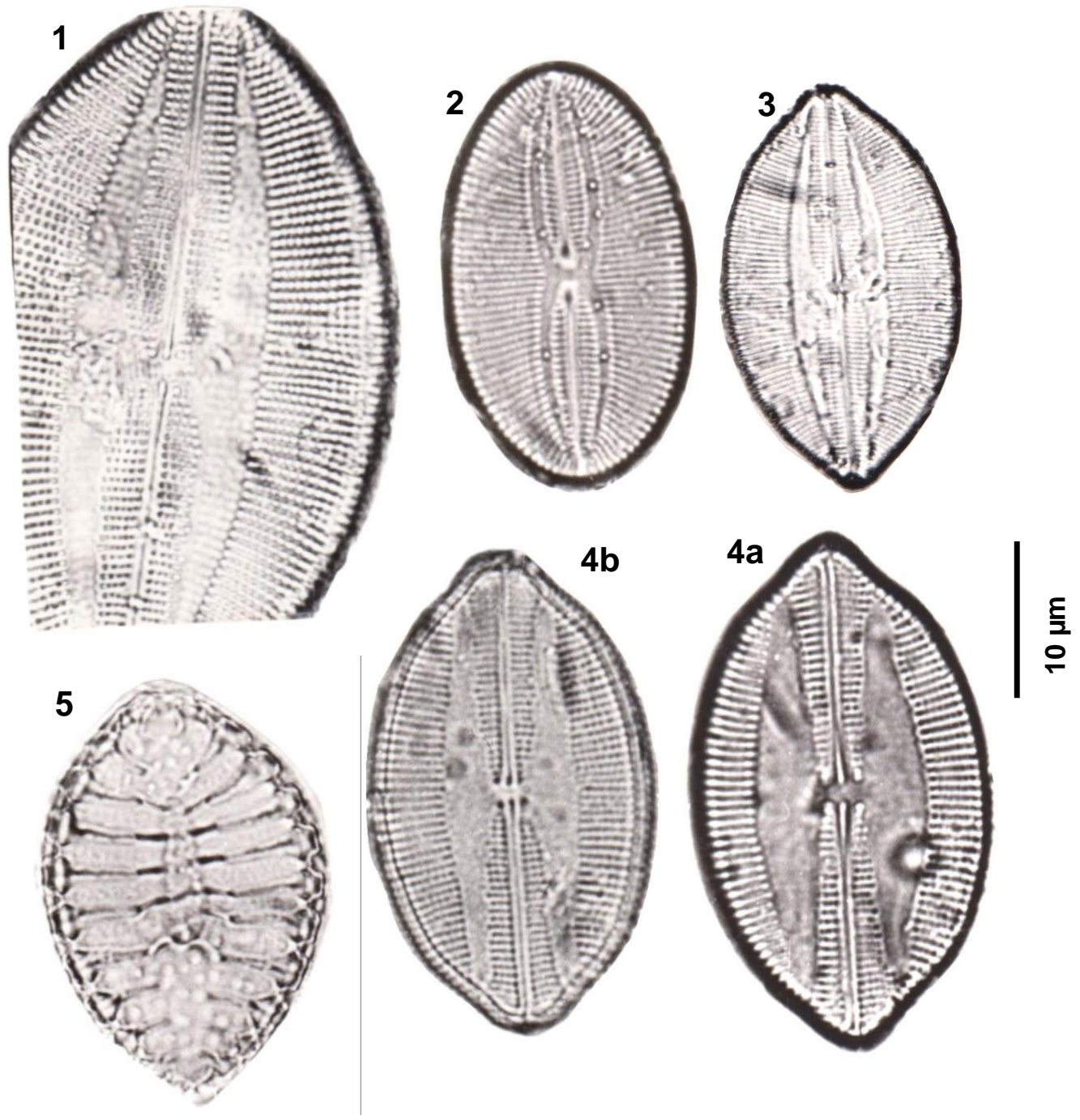

Plate (8): 1. Lyrella lyra (Ehrenberg) Karajeva, 2. L. hennedyi (W.Smith) Stickle \& D.G.Mann, 3. L. lyroides (Hendey) D.G.Mann, 4 a \& b. Navicula clavata Gregory, 5. Surirella fastuosa (Ehrenberg) Ehrenberg. (Scale bar $=10 \mu \mathrm{m})$ 